\title{
Symbol of the War - But Which One? The St George Ribbon in Russian Nation-Building
}

\section{PÅL KOLSTØ}

STATE-SPONSORED national symbols provide nodal points around which people can develop a common political identity. ${ }^{1}$ States need the support of the overwhelming majority of the population in order to survive in the long term. As Margaret Canovan has argued, a state that fails to garner this kind of support will eventually be supplanted by one that does. ${ }^{2}$ However, as pointed out by Michael Walzer, 'the state is invisible; it must be personified before it can be seen, symbolized before it can be loved, imagined before it can be conceived'. ${ }^{3}$ Symbols provide such visual and auditive identification anchors. ${ }^{4}$

State leaders normally prefer to present their symbols as having been part of the national tradition since time immemorial. However, as Eric Hobsbawm and Terence Ranger have pointed out, no tradition has 'always' existed; there is a particular starting point in time, surprisingly often of very recent provenance. 5 Since recently created state symbols are not

Pål Kolstø is Professor of Russian and Post-Soviet Studies in the Department of Literature, Area Studies and European Languages at the University of Oslo.

This article emanates from the research project, 'Discourses of the Nation and the National', at the Department of Literature, Area Studies, and European Languages, University of Oslo (http://www.hf.uio.no/ilos/english/research/projects/disourses-of-thenation/). The author would like to thank Maryia Rohava, Johanna Dahlin and SEER's three anonymous reviewers for their valuable comments on a draft version.

1 Pål Kolstø, 'National Symbols as Signs of Unity and Division', Ethnic and Racial Studies, 29, 2006, 4, pp. 676-701.

2 Margaret Canovan, Nationhood and Political Theory, Cheltenham, 1996, p. 22.

3 Michael Walzer, 'On the Role of Symbolism in Political Thought', Political Science Quarterly, 82, pp. 191-205 (p. 194). Quoted in David I. Kertzer, Ritual, Politics, and Power, New Haven, CT, 1988, p. 6.

4 Kolstø, 'National Symbols'.

5 Eric Hobsbawm and Terence Ranger, The Invention of Tradition, Cambridge, 1992. 
covered by historical patina their mystique is more fragile than is the case with older symbols. The emotional link between the symbol and the nation cannot be taken for granted; the magician's sleight-of-hand is more difficult to hide. Even so, new symbols and traditions are constantly being designed, some of which eventually establish themselves while others fade into oblivion.

The crucial test of the success of a national symbol is whether it can unite the people and bolster their loyalty towards the state. Here I examine one recently created symbol, the ribbon of St George, which for the last eleven years has been promoted as a symbol of the Soviet victory in the Second World War - or 'The Great Fatherland War', as the Russians prefer to call it. From its modest start in 2005, the ribbon campaign has become a major societal and political event, involving millions of participants in various activities in the weeks leading up to Victory Day, 9 May. ${ }^{6}$ In 2015, on the 7oth anniversary of the end of the war, orange-and-black striped St George ribbons were distributed to and worn by millions of Russians, in addition to thousands of people in dozens of other countries. The new ribbon tradition was interwoven with another recently created ritual, the 'Immortal Regiment', in which relatives of deceased war veterans walk through cities bearing photographs of their dear ones. The marchers and often also the photographs are adorned with St George ribbons.

As columnist Iulia Latynina has remarked, 'if someone 20 years ago walked into the street on 9 May with an orange and black ribbon, the best he could hope for was that he would not be understood; in the worst case he would be arrested for illegally carrying a sign of military prowess'? Even today, when no one in Russia can fail to understand what the ribbon symbolizes, it is not universally embraced. On the eve of the victory celebrations in 2015 the Russian police closed down an art exhibition in Moscow called 'We won!' ${ }^{8}$ The title of the exhibition was clearly ironical, its message strongly critical towards the Russian authorities and not least towards what the organizers perceived as a cynical capitalization of the memory of the war for political purposes. One of the artefacts depicted

6 Dmitrii Beliaev, 'Sviazannye odnoi tsel'iu: V Rossii nachalas'aktsiia "Georgievskaia lentochka"' (Tied Together by a Common Aim: In Russia the St George Ribbon Action has Begun), Rossiiskaia gazeta, 24 April $2010<$ http://m.rg.ru/2010/o4/23/lentochka.html>.

7 Iuliia Latynina, 'Georgievskaia lentochka - eto vam ne flaer' (The St George Ribbon Shouldn't Be Used as a Flyer), Novaia gazeta, 12 May $2014<$ http://www.novayagazeta.ru/ columns/63533.html>.

8 'Politsiia razgromila vystavku "My pobedili" v Moskve' ('Police Broke Up the Exhibition "We won!" in Moscow'), 8 May 2015, BBC <http://www.bbc.com/russian/ russia/2015/05/150508_moscow_gallery_police>. 
was a meat-mincer which was fed by green plastic soldier figurines: out of this kitchen utensil came long strips of orange and black ribbon - clearly a reference to the 'little green men' who in March 2014 invaded Crimea prior to the peninsula's incorporation into Russia, as well as to the role Russian soldiers have been playing in the undeclared war in Donbass (see fig. 1).

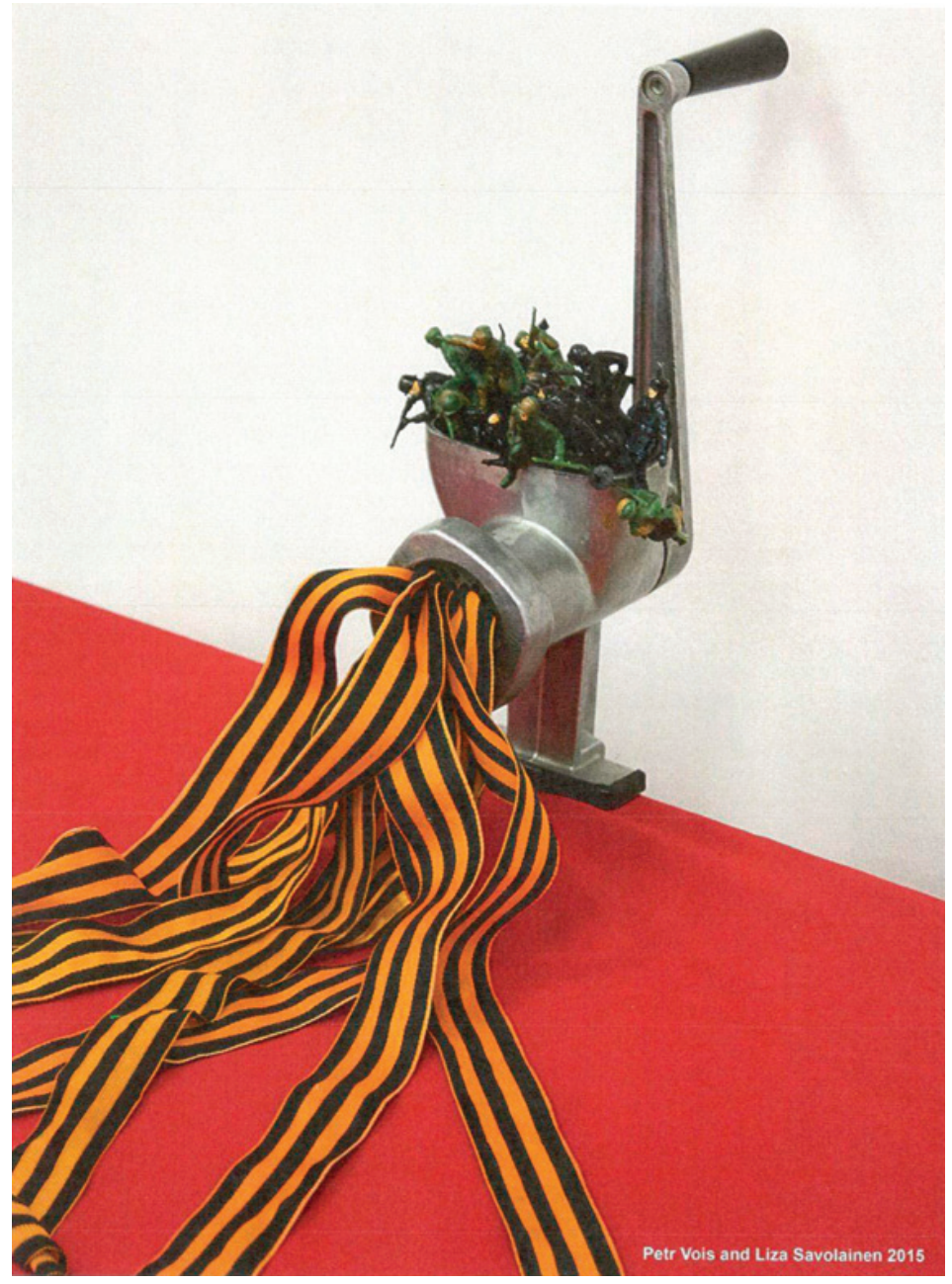

Fig. 1. Petr Vois and Liza Savolainen, 'Miasorubka', 2015. Exhibited in 'My pobedili' at Galereia S.ART, Moscow, 7 May-7 September, 2015. All rights reserved. 
In his blog on the website of the Ekho Moskvy radio station, the commentator Boris Vishnevskii wrote that far from being a 'a symbol of unity', the St George ribbon has turned into 'a symbol of discord'. If so, it must be regarded as a failure, since the main purpose of any state symbol is precisely to unite the population.

In this article I briefly discuss the role of symbols in nation-building theory, and then chronicle the short but eventful history of the ribbon of St George as a newly invented state symbol in Russia, focusing on its ability to unite the population. I discuss why this particular symbol was chosen, by whom and why, the reactions to it and how its meaning is constantly changing.

\section{Symbolic nation-building}

The theoretical literature on nation-building highlights two aspects of the capacity of symbols to produce social cohesion: the internal and the external perspective. While the first focuses on relations within groups, the other understands group cohesion as a function of the contrast with other groups through the erection of group boundaries. These two aspects are not mutually exclusive. Examination of the St George ribbon shows that one and the same symbol may be seen to perform both tasks at the same time. It may obscure ideological and cultural differences between some subgroups in the community while also excluding and erecting boundaries against others.

As argued by Gabriella Elgenius, '[s]ocial life is a repository of symbols, whether in the form of flags, ceremonies, heroes, icons, capitals, statues, war memorials, museums or football teams, which - at their core mark, celebrate and glorify social groups'. However, she warns against a functionalist Durkheimian interpretation that sees this as always and everywhere producing consensus and unity: 'cohesion and solidarity need not follow. ${ }^{10}$

In contrast to other kinds of signs, such as icons and indeces, symbols have no fixed meaning. Abner Cohen defines symbols as 'objects, acts, relationships or linguistic formations that stand ambiguously for a multiplicity of meanings, evoke emotions, and impel men to action'. ${ }^{11}$ The

9 Boris Vishnevskii, 'Ot simvola edinstva - k simvolu raz' edineniia' (From a Symbol of Unity to a Symbol of Division), Ekho Moskvy, 6 May $2015<$ http://echo.msk.ru/blog/ boris_vis/1543916-echo/>.

${ }^{10}$ Gabriella Elgenius, 'The Politics of Recognition: Symbols, Nation Building and Rival Nationalisms', Nations and Nationalism, 17, 2011, 2, pp. 396-418, (p. 397).

${ }^{11}$ Abner Cohen, Two-Dimensional Man, Berkeley, CA, 1976, p. 23, italics in the original. 
meaning of a symbol cannot be deduced. Symbols have value and meaning only for those who recognize them. ${ }^{12}$ The inherently ambiguous character of symbols makes them eminently usable for nation-building purposes. ${ }^{13}$

In his celebrated study of the symbolic construction of community, Anthony Cohen maintains that 'symbols do not so much express meaning as give us the capacity to make meaning. ${ }^{14}$ Because symbols are malleable, they may be made to 'fit' the circumstances of the individual. The range of meanings in concepts such as patriotism, duty, love and peace can be glossed over in a commonly accepted symbol - precisely because it allows its adherents to attach their own meanings to it. 'They share the symbol, but do not necessarily share its meanings. ${ }^{15}$ However, I hold, this view stretches too far the ability of symbols to 'sweep differences under the carpet'. It presupposes that members of society are unaware of, or at least ignore, the fact that their fellow-citizens may attach different, sometimes even opposite, meanings to symbols. This assumption is unwarranted for the simple reason that people communicate not only through (non-verbal) symbols but also through (the verbal symbol of) language. As David Kertzer points out: 'The American flag can be as valuable to the civil rights marchers as to the Ku Klux Klan in defining what is good for the community. ${ }^{\prime 16}$ We may legitimately ask how the flag in such a situation can be said to contribute to feelings of social solidarity and recognition among the various flag-bearers that they belong to the same community.

Symbols are indeed ambiguous, but they do not necessarily or always play the solidifying role in society that Anthony Cohen presupposes. Their ambiguity becomes apparent when they are talked about in different contexts by different groups espousing disparate national agendas. Modern society is pluralistic in structure, consisting of various groups that overlap, cut across, support or oppose one another. ${ }^{17}$ National symbols, Michael Geisler reminds us, are heatedly contested just as often as they are embraced. ${ }^{18}$ It therefore seems more fruitful to regard nations, as John

${ }_{12}$ Montserrat Guibernau, Belonging: Solidarity and Division in Modern Societies, Cambridge, 2013, p. 37.

${ }_{13}$ Anthony Cohen, The Symbolic Construction of Community, London, 2007, p. 23; Guibernau, Belonging, pp. 38 and 97; Kertzer, Ritual, p. 11; Zdzislav Mach, Symbols, Conflict, and Identity: Essays in Political Anthropology, New York, 1993, pp. 30, 51.

14 Cohen, Symbolic Construction, p. 15.

15 Ibid.

${ }^{16}$ Kertzer, Ritual, p. 92.

17 Cohen, Two-Dimensional Man, p. 87.

${ }^{18}$ Michael Geisler, (ed.), National Symbols, Fractured Identities: Contesting the National Narrative, Hanover, NH, 2005. 
Hutchinson does, as 'zones of conflict'. ${ }^{19}$ Within nations, 'cultural wars' are waged between groups that see themselves as members of the same nation but uphold different visions of what that nation is or ought to be. '[T]hese rival symbolic repertoires, in appealing to multiple class and status groups, do not so much express sectional struggles as different visions of the nation. ${ }^{20}$

In an influential article from 1969, Fredrik Barth argued that the perceived boundary between social groups is crucial for the crystallization of their respective collective identities. ${ }^{21}$ Whereas the traditional understanding had been that groups are held together by the 'cultural stuff' they have in common, Barth maintained that their identity formation hinges upon their mutual differentiation. As a social anthropologist, Barth focused on the role of boundary-markers - or 'diacritica' - in relations between ethnic groups; later researchers have expanded this approach to include also the study of nationalism. ${ }^{22} \mathrm{He}$ concentrated almost exclusively on material and visible objects as boundary-markers: however, the boundaries are not something 'out there' but are located in people's heads, in 'the minds of their beholders. ${ }^{23}$ Therefore, immaterial boundary markers such as myths and symbols are at least as important as material diacritica. ${ }^{24}$

Barth's concept of the boundary, I argue, can be extended to the study not only of national and ethnic groups but also to social groups within the putative nations. ${ }^{25}$ It can fruitfully be employed to a study of contentious politics among various groups who engage in struggles to define 'the nation' - what Hutchinson calls 'cultural wars'. Also here symbols will appear as both weapons and bones of contention.

\section{Picking symbols from an almost empty toolbox?}

Russia has a chequered political history, punctuated by revolutions and counterrevolutions. Today, the symbols of each period in the country's past have their aficionados and detractors. While many Russian nationalists and imperialists draw on imagery from both the pre- and post-Revolutionary

19 John Hutchinson, Nations as Zones of Conflict, London, 2005.

${ }^{20}$ Ibid., p. 87.

${ }^{21}$ Fredrik Barth, Ethnic Groups and Boundaries, Oslo, 1969; Siniša Malešević, The Sociology of Ethnicity, London, 2004; Andreas Wimmer, Ethnic Boundary Making: Institutions, Power, Networks, Oxford, 2013.

${ }^{22}$ See, for example, Thomas Hylland Eriksen, Ethnicity and Nationalism, London, 1993.

${ }^{23}$ Cohen, Symbolic Construction, p. 12. See also, Guibernau, Belonging, p. 37.

${ }^{24}$ John Armstrong, Nations before Nationalism, Chapel Hill, NC, 1982, pp. 8-9; Pål Kolstø, 'Assessing the Role of Historical Myths in Modern Society', in id. (ed.), Myths and Boundaries in South-Eastern Europe, London, 2005, pp. 1-34.

${ }_{25}$ Pierre Bourdieu, Language \& Symbolic Power, Cambridge, MA, 1991, pp. 120-24. 
periods, tsarist symbols continue to be anathema to diehard Communists, while Communist symbols are abhorred by most Orthodox believers. The main public holiday in the Soviet period, the celebration of the October Revolution on 7 November, was discontinued during Boris El'tsin's years in power, and attempts to establish alternative 'national days' proved less than successful. ${ }^{26}$ The official 'Russia Day' on 12 June does not count for much in Russian society, while the 'Day of National Unity', 4 November, has been seized upon by right-wing nationalists seeking to turn its official message on its head: the main slogan during their 'Russian marches' is 'Russia for [ethnic] Russians', a clear provocation to non-Russian minorities. ${ }^{27}$

The El'tsin administration failed to achieve consensus in the political elite on the national symbols for the new Russia. Neither the reintroduction of the white-blue-red tricolour nor the attempt to resurrect Glinka's patriotic melody as a national anthem achieved the necessary votes in the Duma to become official state symbols; in the end, they were sanctioned into law by presidential decree. ${ }^{28}$ However, symbols that are foisted upon a reluctant population are inevitably unable to fulfil their most important task: to unite people and give them a common purpose and identity.

Shortly after having taken office as president, Vladimir Putin brought the thorny issue of national symbols back to the table and managed to steer it through parliament. His packet solution was a compromise: the white-blue-red tricolour was retained as the country's flag, while the new national anthem is a refashioned version of the Soviet anthem. The words were new but written by the same author, Sergei Mikhalkov, a popular author of children's books who during the Second World War had penned the original version. While some dissidents denounce the anthem as Stalinist, ${ }^{29}$ it has been almost universally embraced in Russian society: Putin had hit upon an important source of regime support. Evidently, he and his advisers concluded that the Victory in the war should be tapped even more for political legitimation, and preferably in ways without strong associations to Stalinism.

\footnotetext{
${ }^{26}$ Kathleen E. Smith, Mythmaking in the New Russia: Politics and Memory during the Yeltsin Era, Ithaca, NY, 2002.

${ }^{27}$ Alexander Verkhovsky, 'Radical Nationalists from the Start of Medvedev's Presidency to the War in Donbas - True till Death?', in Pål Kolstø and Helge Blakkisrud (eds), The New Russian Nationalism: Imperialism, Ethnicity, Authoritarianism 2000-2015, Edinburgh, 2016, pp. 92-96.

${ }^{28}$ Pål Kolstø, 'Nation-Building in Russia: A Value-Oriented Strategy', in Pål Kolstø and Helge Blakkisrud (eds), Nation Building and Common Values in Russia, Lanham, MD, Boulder, CO and New York, 2003, pp. 1-28.

${ }^{29}$ Lilia Shevtsova, Putin's Russia, Washington, D.C., 2003, pp. 144-46.
} 
The major contribution of the Soviet Union to the defeat of Nazi Germany is indisputable; in absolute figures, Soviet war losses were incomparably greater than those of any other combatant nation. The Soviet regime did whatever it could to extract legitimacy from this fact, and from the mid-196os 9 May was celebrated each year with considerable fanfare. As in some other countries, not least in France, a huge military parade inspected by state leaders was the main feature of the celebrations, but there were also numerous local celebrations throughout the country. Even so, as Christel Lane points out, this public ritual was more decentralized and restrained than the other two major Soviet holidays - International Workers' Day on 1 May and the October Revolution on 7 November..$^{30}$

In 1965, Victory day was officially instituted as a public holiday. Celebrations normally began the day before, with a ceremony at various workplaces - the kollektivy. Early the next morning the townspeople gathered around the local war memorial for a wreath-laying ceremony. The guard of honour was usually made up of three generations, as a relay of memory. A standard ingredient in the ceremony would be a roll-call of the dead, and for each name a Pioneer youngster would step forward and declare: 'he died the death of the brave. ${ }^{31} \mathrm{~A}$ brass band would play, a poem would be recited and there would be a one minute silence. War veterans would be in attendance wearing all their medals.

The Soviet Union always celebrated Victory Day one day after the rest of Europe, a tradition which has been retained in Russia. Technically, this resulted from the time difference between Moscow and continental Europe; when the German surrender was signed on 8 May in Berlin, it was already past midnight in the Soviet capital. Gradually, this calendar difference acquired a symbolic subtext: the USSR had fought its own, parallel war with Nazi Germany - the Great Fatherland War, or 'VOV' in its Russian acronym. The Soviet war effort was rarely referred to as part of 'the Second World War'. While the Second World War started on 1 September 1939, the Great Fatherland War began nearly two years later, with the German invasion of the USSR on 22 June 1941.

In the late Soviet period there was some evidence that enthusiasm for the victory celebrations was flagging - in particular, the younger generations were not taking it to heart. An entire ten-day period at the beginning of May - starting with International Workers' Day on 1 May and ending with Victory Day - was a more or less continuous holiday

${ }^{30}$ Christel Lane, The Rites of Rulers: Ritual in Industrial Society: The Soviet Case, Cambridge, 2010, p. 143.

${ }^{31}$ Ibid. p. 145 . 
season, mainly celebrated with vodka and good food on family picnics. On that day, 'they' (the state leaders) were doing 'their things' in the public arena, things which did not necessarily concern 'ordinary people'. The Putin regime was determined to change this aloofness: a new, officially sanctioned history-writing returned victory in the Great Fatherland War to the centre of regime legitimation. ${ }^{32}$

The first St George ribbons were worn by ordinary Russians in 2005 . The ribbon is modelled on a high-ranking order instituted by the Stalin regime in 1942. It has the same colours as the Soviet medal but a different name: the Soviet prototype was called 'Order of the Guard' (gvardeiskii orden). Its colours - orange and black - are said to symbolize fire and gun-smoke. Both the Order itself as well as various kinds of ornamentation in orange and black featured on numerous wartime and post-war posters and postcards (see figs 2 and 3 ). ${ }^{33}$

Why was the new commemorative ribbon introduced under Putin called 'St George' (georgievskii) and not 'gvardeiskii'? An Order of St George 'for service and valour' had been instituted by Catherine the Great in 1769 , and clearly Stalin was deliberately drawing on associations with this order when he introduced his own. ${ }^{34}$ However, he had not only changed the name, but also readjusted the image somewhat: the original St George order had been yellow and black, or occasionally golden and black; the orange colour was introduced by the Communists (see figs 4 and 5 , respectively).

In this way the Soviets managed to signal both continuity and change with the pre-Revolutionary symbolism. In a strikingly similar manner the new commemorative St George ribbon introduced under Putin eclectically combines elements from both previous periods: the name is taken from the tsarist order and the colour nuances from the Soviet army emblem. ${ }^{35}$

\footnotetext{
${ }^{32}$ A detailed ' historical-cultural standard' for patriotic education for use in all schools has been launched. See <http://histrf.ru/biblioteka/book/istoriko-kul-turnyi-standart>.

33 See, for instance, the many illustrations in Albert Lex's LiveJournal blog: <http:// albert-lex.livejournal.com/28216.html >.

34 In Orthodox hagiography St George is referred to as 'St George the Victorious' (Pobedonosets). On the breast of the double-headed eagle in the Russian coat of arms he is depicted slaying a dragon.

35 Igor' Eliseev, 'Kak i kogda poiavilis' georgievskaia i gvardeiskaia lentochki' (How and When Did the St George Ribbon and the Guard Ribbon Appear?), Rossiiskaia gazeta, 6 May $2015<$ http://m.rg.ru/2015/05/o7/lentochka.html $>$.
} 


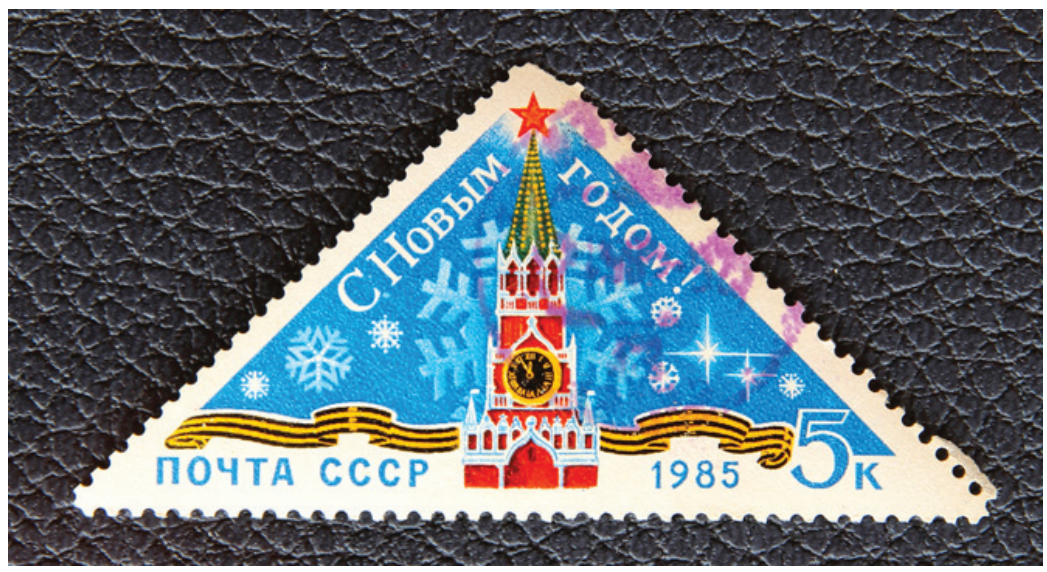

Fig. 2. New Year stamp showing the Moscow Kremlin, USSR, 1985.

(c) Kingarion / Shutterstock.com

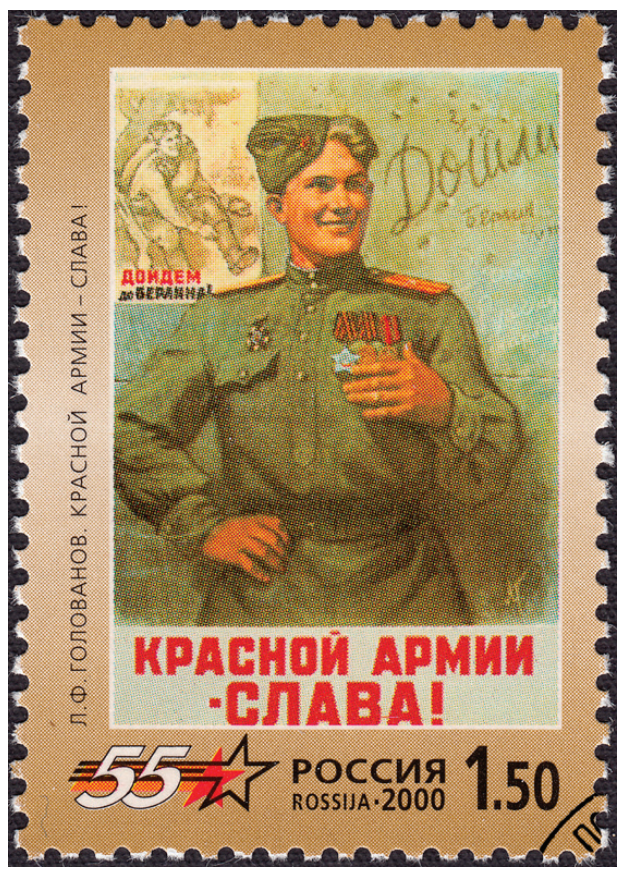

Fig. 3. 'Krasnoi armii - slava!', by L. F. Golovanov. 1 ruble 50 Russian postage stamp, 2000. 


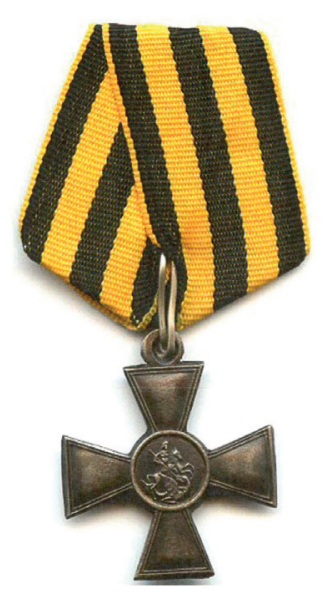

Fig. 4

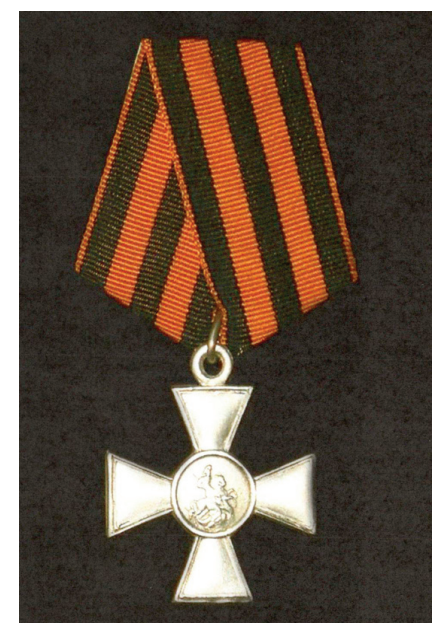

Fig. 5 .

Galereia S.ART. All rights reserved.

Moreover, the Order of St George was used also by General Vlasov's Russian Liberation Army, which fought on the side of the Axis Powers during the final years of the Second World War. Thus, the emblem can be associated with three very different political systems: tsarism, Communism and fascism. Hardly anyone in Russia draws a line from the vlasovites to today's St George ribbon, ${ }^{36}$ as is done in other post-Soviet states.

Most observers take for granted that the St George commemorative ribbon was introduced into Russian political imagery by state fiat. This may or may not be correct: but if it is, it is not something the authorities will readily admit to. Officially, it is claimed that the initiative for the ribbon campaign (or 'action' - aktsiia) was 'spontaneous' (stikhiino), ${ }^{37}$ meaning that it emanated from society and not from the state authorities. The roots of the action may be traced back to the civil society organization, 'Student Community' (Studencheskaia obshchina); their original objective was to keep the memory of the Victory alive among the younger generations. Political scientist Mikhail Savva explains: 'Much has been said about the broken bond between the generations in our country, and that is indeed

${ }^{36}$ An exception is the leftist journalist Alexander Nevzorov, who is highly critical to the St George ribbon. See 'Tvorcheskii vecher Nevzorova, v kontsertnom zale u Finliandskogo', Nevzorov.TV, 19 April 2014 <http://nevzorov.tv/2014/04/tvorcheskij-vecher/>.

37 'Lentochka nashei pamiati. Istoriia aktsii "Georgievskaia lentochka"' (A Ribbon for Our Memory: The History of the 'St George Ribbon Action'), Argumenty i fakty, 27 April $2010<$ http://www.aif.ru/society/history/17737>. 
true. And no one had so far come up with a better means of restoring this connection than this joint work towards a common goal. ${ }^{38}$ According to the article on Studencheskaia obshchina in the Russian Wikipedia, this is 'one of the few social youth organizations in [Moscow] which is financially and politically independent ${ }^{39}$ However, this information should probably be taken with a pinch of salt, as the Wikipedia editors have equipped the article with a warning that makes it look suspiciously like a public relations piece. Be that as it may, we can conclude that the story about the civil society origins of the ribbon symbol is a vital part of the 'action' itself.

The target group of the St George action has been expanded: no longer an educational programme aimed at youth only, it reaches out to all Russian citizens at home and abroad, indeed to anyone anywhere who wants to pay tribute to the Soviet war effort. The main slogans are 'Thank you, granddad, for the Victory', and 'I remember - I am proud'.

The students in 'Student Community' apparently needed some informational structures through which to disseminate their campaign message, and contacted Natalia Loseva at the news agency RIA Novosti. Since RIA Novosti is an official agency of the Russian state, Loseva is unlikely to have agreed to participate in this endeavour without the consent of her superiors. ${ }^{40}$

Iulia Latynina insists that the timing of the first ribbon campaign was not fortuitous: it was launched after the Orange Revolution in Ukraine, and must be seen as a deliberate attempt to forestall any 'colour revolution' in Russia. ${ }^{41}$ Even the orange colour was purloined from the Maidan activists, she claims. While this is an intriguing interpretation, there is little evidence to support it. We can also note that the campaign had a rather long fuse before it exploded into the mega-event it has become today. Not until 2007 - during the third year of the campaign - was the ribbon officially worn by Vladimir Putin for the first time. Later, both he and Dmitrii Medvedev would wear it on each Victory day celebration (see fig. 6). ${ }^{42}$

38 Mikhail Savva, 'Mai prodolzhaetsia' (May is Continuing), Rossiiskaia gazeta, 5 December $2006<$ http://www.rg.ru/2006/12/05/savva.html>.

39 'ROSSPM“'Studencheskaia obshchina”" <https://ru.wikipedia.org/wiki/Студенческая_ община> .

${ }^{40}$ According to one version the idea to launch the St George ribbon campaign originated with Natalia Loseva. See, for example, “Georgievskaia lentochka” prevrashchaetsia v instrument piara i aksessuar odezhdy', (The St George Ribbon is Being Turned into an Instrument of Public Relations and a Clothing Accessory'), Gazeta <http://www.gazeta. spb.ru/152358-o/>.

${ }^{41}$ Iuliia Latynina, 'Kod dostupa' (Entrance Code), Ekho Moskvy, 2 May $2015<\mathrm{http}: / / \mathrm{m}$. echo.msk.ru/interview/detail.php? $\mathrm{ID}=1541010>$.

${ }^{42}$ 'Lentochka nashei pamiati'. 


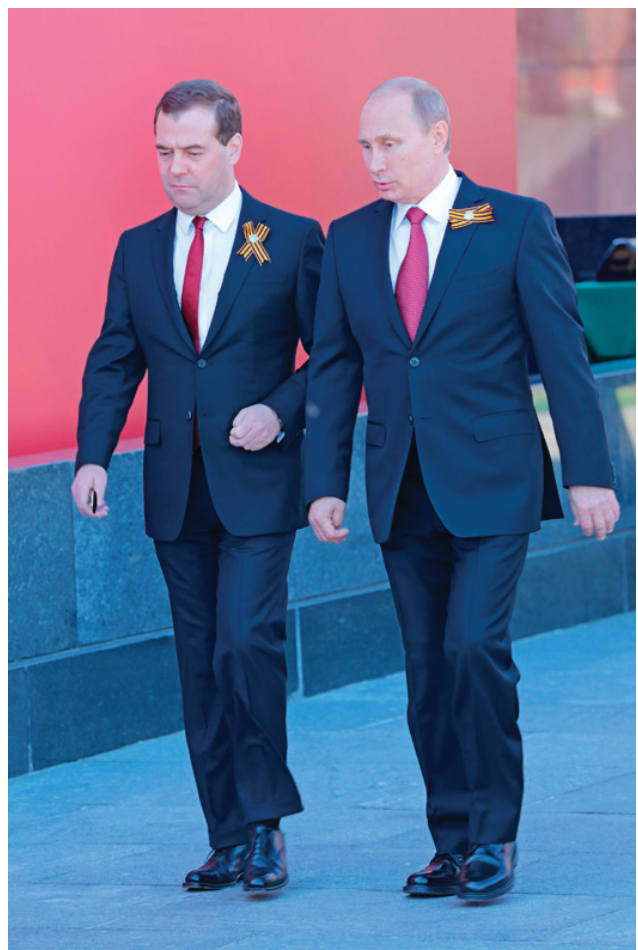

Fig. 6. Dmitrii Medvedev (left) and Vladimir Putin (right), Moscow, Russia May 09, 2014: Celebration of the 69th anniversary of the Victory Day (WWII) on Red Square. ( ID1974 / Shutterstock.com

From a relatively modest start, the campaign has grown in size and significance. While 800,000 ribbons were manufactured in $2005^{43}$ and six million in 2006, by 2010 six million were not enough to meet demand even in Moscow city alone. It became necessary to introduce restrictions on how many ribbons each individual could pick up at the distribution points: a limit of three was imposed. ${ }^{44}$ Various sponsors - commercial and official - financed the production of the ribbons that were sewn at textile factories all around the country. In 2015 one textile mill in Kazan' alone rolled out no less than $10,000 \mathrm{~km}$ of ribbon. ${ }^{45}$

43 Marina Poroshina, 'Gvardii shtof. Georgievskuiu lentu izpol'zuiut dlia reklamy spirtnogo' (A Glass Flask for the Guard: The St George Ribbon is Used as an Advertisement for Alcohol), Rossiiskaia gazeta, 8 May $2007<$ http://www.rg.ru/2007/05/o8/reg-ural/lenta. html>.

${ }^{44}$ Beliaev, 'Sviazannye odnoi tsel'iu'.

45 Kirill Antonov, 'V Kazani vypustiat 10 tysiach kilometrov georgievskoi lenty' (In Kazan' 10,000 km of St George Ribbon Will Be Produced), Kommersant, 4 March 2015 
Activist groups in several cities have produced supersized ribbons, aimed at getting into the Guinness Book of Records: a 3.5 x 50 m specimen made of one seamless piece of cloth was produced in Simferopol in Crimea in $2009,{ }^{46}$ but this record was surpassed the next year in Odessa when a $6 \times 142$ m ribbon was carried down the famous Potemkin steps by 12,000 people (see fig. 7). ${ }^{47}$

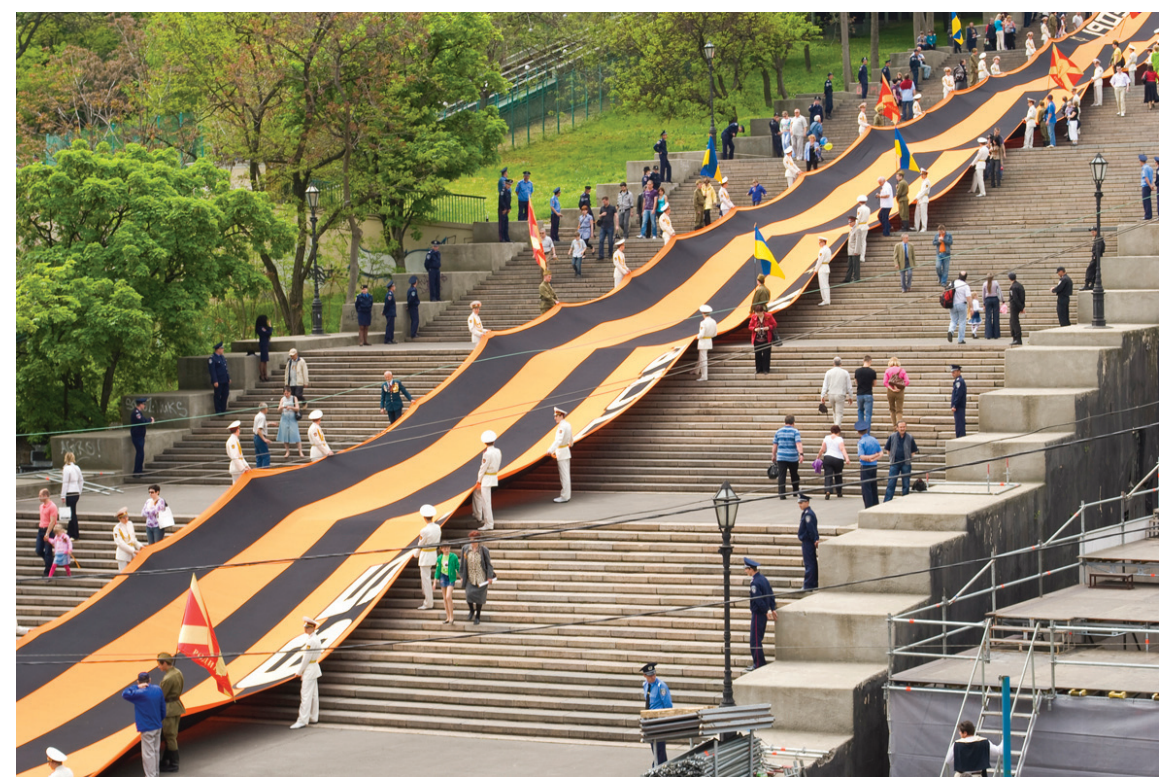

Fig. 7. A huge ribbon of St. George is presented on the Potemkin Steps for the Victory day May 8, 2010 in Odessa, Ukraine. (C) Slav Bukhal / Shutterstock.com

The record so far seems to have been set in Stavropol in 2013 when local citizens could proudly exhibit a 500 metre-long ribbon. ${ }^{48}$ In 2008 ribbons

$<$ http://www.kommersant.ru/doc/2679616>.

46 'Samaia bol'shaia v mire Georgievskaia lentochka sdelana v Simferopole' (The World's Biggest St George Ribbon Made in Simferopol), RIA Novosti, 8 May $2009<\mathrm{http} / /$ ria.ru/society/20090508/170381613.html>.

47 'Odessa: Potemkinskuiu lestnitsu nakryla gigantskaia Geogrievskaia lenta (foto)' (Odessa: A Gigantic St George Ribbon Covered the Potemkin Stairs [photo]) <http://timerodessa.net/news/odessa-potemkinskuyu-lestnicu-nakryla-gigantskaya-georgievskayalenta.html>.

${ }^{48}$ Svetlana Emel'ianova, 'Iz Stavropolia Georgievskaia lenta otpravilas' po strane' (From Stavropol the St George Ribbon has been Sent Around the Country), Rossiiskaia gazeta, 29 April 2013 <http://www.rg.ru/2013/o4/29/reg-skfo/pobeda.html>. A major intention of manufacturing this gargantuan ribbon was to demonstrate inter-ethnic harmony in the restive North Caucasian region. The ribbon was produced by students 
were distributed in thirty countries, ${ }^{49}$ and then to more than sixty countries the next year. ${ }^{50}$

To explain the success of the campaign, commentators note how the ribbon 'ties' people together. While the campaign has occasionally been used to collect money to support veteran organizations, Rossiiskaia gazeta avers that this is not its chief purpose: 'The main thing in the campaign, of course, is not money, but its spirit, the idea - to unite the nation around the Great Victory. ${ }^{51}$ Summing up the second campaign in 2006, Rossiiskaia gazeta argued that 'a country on the rise is in need of symbols of national unity':

[The ribbon] not only unites us with our recent past, but also with each other. To be reminded about our civil unity by means of the St George ribbon is extraordinarily important. Far too many dividing lines run through the Russian nation - from differences in income levels, to different political viewpoints and different nationalities. ${ }^{52}$

In Kommersant, Elizaveta Surnacheva wrote, 'the Victory has turned out to be the main if not the only spiritual "tie" [skrepa] of Russian statehood.53 Similarly, an unsigned editorial in Nezavisimaia gazeta in April 2015 maintained that 'the victory in The Great Fatherland War, the 7oth anniversary of which Russia is celebrating next week, remains one of the very few symbols that can unite citizens with different convictions, attitudes towards the authorities, and social status. ${ }^{54}$ Leading sociologist and pollster Lev Gudkov claims that Victory Day is 'the only opportunity for the nation to assert itself. There are no other foundations left for national pride. ${ }^{55}$ Such sentiments seem to be an important part of the reason why the St George ribbon was chosen as a rallying symbol for the

from all seven federal subjects in the North Caucasian Federal Okrug as a token of interethnic brotherhood.

49 'Lentochka nashei pamiati'.

${ }^{50}$ Beliaev, 'Sviazannye odnoi tsel'iu'.

${ }^{51}$ Elena Ivanova, 'Pamiat' ognennogo tsveta' (A Fire-Coloured Memory), Rossiiskaia gazeta, 12 May 2008 <http://www.rg.ru/2008/05/12/reg-kuban/georglenty.html>.

52 Savva, 'Mai prodolzhaetsia'.

53 Elizaveta Surnacheva, 'Lentochnyi konveier: kak zarabotat' na patrioticheskikh chuvstvakh' (A Ribbon Conveyor: How to Make a Profit from Patriotic Emotions), Kommersant, 11 May $2015<$ http://www.kommersant.ru/doc/2714479>.

54 'Velikaia Pobeda: deistvitel'no odna i deistvitel'no na vsekh' (The Great Victory: Indeed, It is Only One and Indeed for Everyone), Nezavisimaia gazeta, 30 April 2015 <http://www.ng.ru/editorial/2015-04-30/2_red.html>.

55 'V-day in Russia Evokes National Pride at Difficult Time', Associated Press, 7 May 2015 . 
regime. Listeners to the semi-independent radio station Ekho Moskvy were told that the St George ribbon had been concocted 'as a symbol of the only event in the history of our Fatherland able to unite the entire country - the victory.56 And finally, according to three journalists in Komsomol'skaia Pravda, the St George ribbon is 'perhaps the only symbol of the victory which can unite the entire people..$^{57}$ The authors of these remarkably similar assessments span the entire spectrum of political orientations in Russia, from Putinists who gladly pin the ribbon onto their chests, to oppositionists who scorn it as a symbol of subservience to an authoritarian regime. A common premise for them all seems to be that national unity in Russia cannot be taken for granted. It is a sensitive plant that must be cultivated tenderly lest it wither away. The ribbon of St George is one of the few tools left in the authorities' gardening kit.

\section{A victim of its own success? The St George ribbon from popularity to poshlost'} Unlike the red poppies worn by the British on Remembrance Day, St George ribbons are not sold for charity but distributed for free. ${ }^{58}$ It is explicitly stated in the charter of the St George action that it should be 'non-commercial'.59 Many Russian private firms and shops, however, have not resisted the temptation to try to profit from the St George craze. This has been done in various ways, either by designing commercials adorned with ornamentation in orange and black, or by charging a certain sum for the ribbons they have for sale. There is a fine line between expressing support for this patriotic action and enriching oneself unreasonably from it. In several cities, self-appointed patriotic vigilantes have taken it upon themselves to determine where that line is to be drawn, and have pilloried in the press shops and firms which in their view have overstepped it. ${ }^{60}$ As one zealot expressed it, 'To make a trade of something which is practically speaking a sacred item [sviatynia] is unethical'. ${ }^{61}$ A pharmacy

${ }^{56}$ Vishnevskii, 'Ot simbola edinstva'.

57 Tatiana Shokareva, Svetlana Khustik and Stanislav Karpovich, 'Georgievskie lenty v etom godu prevratili v sposob nazhivy' (This Year the St George Ribbon has been Turned into a Means of Profit), Komsomol'skaia Pravda, 8 May $2011<$ http://www.kem.kp.ru/ daily $/ 25682 / 841222 /$ ?geoid $=1>$.

58 Even so, many Muscovites have experienced that young people who distribute ribbons in the streets clearly expect to get a 'donation'.

${ }^{59}$ Kodeks aktsii: 'Georgievskaia lentochka'<http://glgmay.ru/about/codex>.

${ }^{60}$ Oleg Khokhlov and Iurii L'vov, 'Kak Pobeda stala dvigatelem torgovli' (How the Victory Became a Motor of Commerce), Kommersant, 11 May $2015<$ http://www.kommersant.ru/ doc/2713642>; Dar'ia Polygaeva, 'Patriotizm zakonodatel'no zapretit' nel'zia' (Patriotism Cannot be Outlawed), Kommersant, 8 May $2015<$ http://www.kommersant.ru/doc/2723786>.

${ }^{61}$ Ekatarina Semenova, 'Magazin kroiki i shit'ia v Pushkine vystavil na prodazhu 
in Krasnoyarsk gave away St George ribbons for free, but only to customers who bought medicine for a minimum of 350 roubles; this was censured as lacking in good taste, while wrapping up salad or liver in orange and black paper is denounced as poshlost', an almost untranslatable word with a meaning somewhere between 'vulgarity' and 'banality'. ${ }^{62}$

Even worse, designs in orange and black have been used to decorate commodities like cheap vodka. ${ }^{63}$ The most egregious case of this kind involved a firm that provided public bio-toilets with orange and black stripes (see fig. 8). ${ }^{64}$ Posing as a People's Tribune, Vladimir Zhirinovskii proposed making illegal any use of Victory symbols in advertising - a move opposed by spokespersons for private business, who argued that 'patriotism should not be banned'. 65

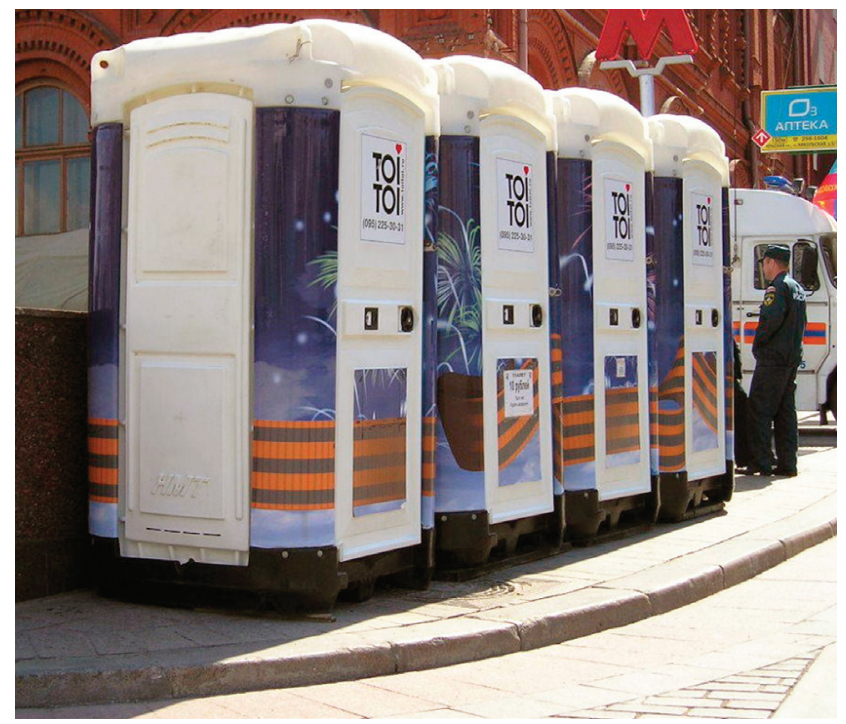

Fig. 8. Galereia S.ART. All rights reserved.

Georgievskie lentochki' (In the City of Pushkin St George Ribbons are On Sale in an Embroidery Shop), Komsomol'skaia pravda, 22 April $2015<$ http://www.spb.kp.ru/ daily/26371.4/3251606/>.

${ }^{62}$ Shokareva, Khustik \& Karpovich, 'Georgievskie lenty'.

${ }^{63}$ Irina Kirsheva and Svetlana Valiulina, 'V krasnoiarskom supermarkete prodaiut deshevuiu vodku, pereviazannuiu georgievskoi lentochkoi' (A Krasnoiarsk Supermarket Sells Cheap Vodka with the St George Ribbon Tied Around the Bottle), Komsomol'skaia pravda, 28 April 2015, http://www.kp.ru/daily/26372/3253933/.

${ }^{64}$ Khokhlov and L'vov, 'Kak Pobeda stala dvigatelem torgovli',

${ }^{65}$ Polygaeva, 'Patriotizm zakonodatel'no zapretit'. 
However, not only business but also ordinary people contributed to the trivialization of the St George action, at least in the opinion of some of the purists. While the ribbon was originally supposed to be pinned onto the lapel, it soon turned up on suitcase handles and children's prams, as well as on cars, not only tied to antenna or inside the front window, but also on license plates. Some 'concerned citizens', particularly of the older generation, perceived impudence when they saw the ribbon used as shoe laces, as body art, around dogs' necks, or attached in abundance all over the body (see figs 9 and 10). ${ }^{66}$

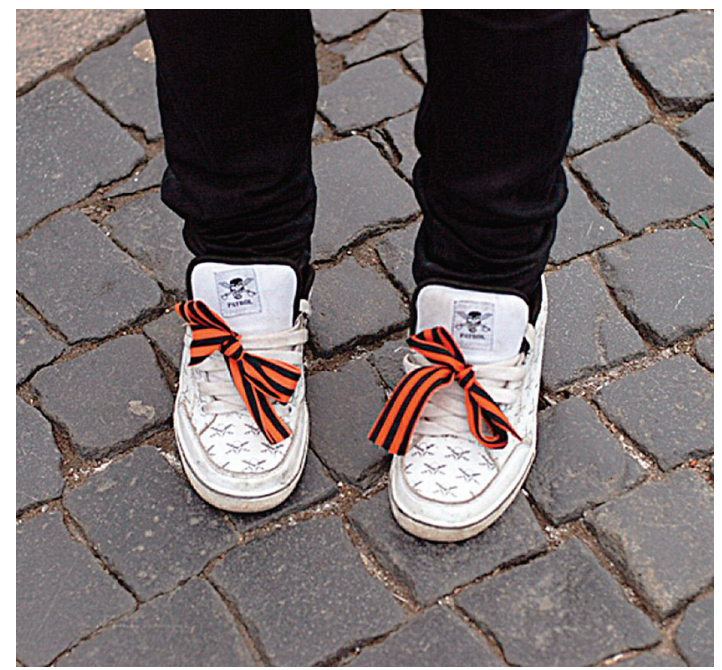

Fig. 9. Trainers. Galereia S.ART. All rights reserved.

Some vigilantes accepted this as an expression 'not of base motives, but simply a lack of taste', while others warned against turning Victory Day into a preposterous piece of buffoonery. ${ }^{67}$ According to some critical voices, 'a massive theatre of the absurd is unfolding before our eyes, which has nothing to do with the Victory which we are commemorating on 9 May'. ${ }^{68}$ Psychiatrist Andrei Bil'zho found reason to warn against turning

66 'Blog-out', 7 May 2015; Ekatarina Simokhina, 'Georgievskaia lentochka i pilotka: "Pomniu, gorzhus'?” ili “Tak modno?”' (The St George Ribbon and the Side-Cap: 'I Remember I am Proud!' or 'Because it is Fashionable?'), Komsomol'skaia Pravda, 5 May $2011<$ http://m.volgograd.kp.ru/daily/25681.4/839750/>.

67 Elena Kriviakina, 'Ne prevrashchaite Den' Pobedy v balagan' (Do Not Turn Victory Day into a Farce), Komsomol'skaia pravda, 23 April $2015<$ http://www.kp.ru/ daily/26371.4/3252273/>.

${ }^{68}$ Vishnevskii, 'Ot simvola edinstva'. 
the St George action into 'a mass psychosis'. ${ }^{69}$ Again, it was difficult to draw the line between playful creativity on the one hand, and disrespect on the other.

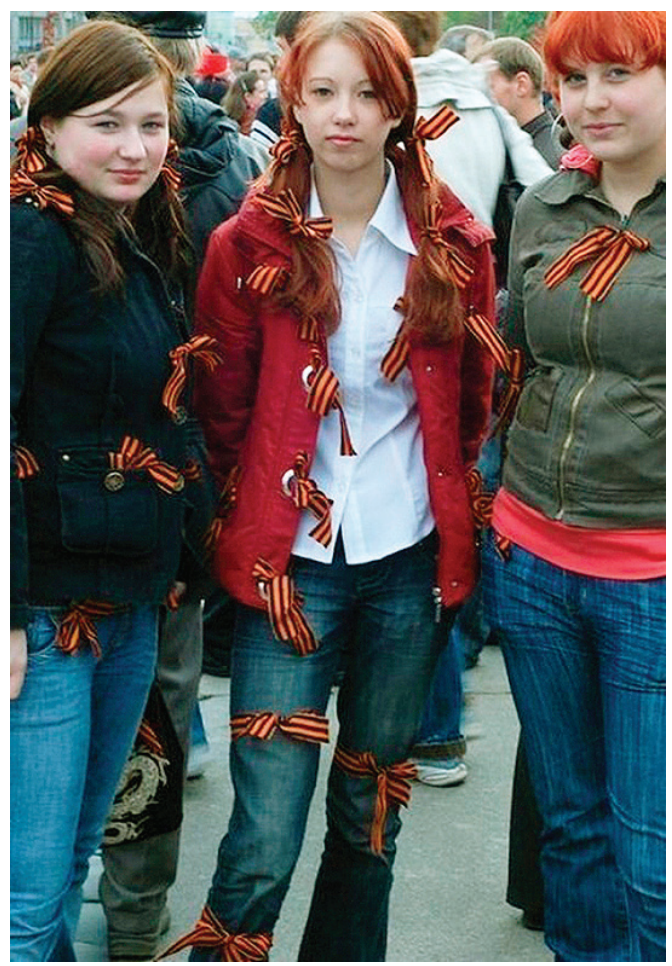

Fig. 10. Galereia S.ART. All rights reserved.

If the 'offender' of the unwritten St George code of conduct was known to be an oppositional, condemnation was particularly harsh - as when Ksenia Sobchak, a prominent anti-Putin liberal, posted pictures of herself on Instagram in a bikini, the lower part of which was orange-and-black striped $7^{70}$

69 “'Situatsiia s georgievskoi lentochkoi blizka k massovomu psikhosu”' (The Situation with the St George Ribbon is Moving Closer to Mass Psychosis), Kommersant, 7 May 2015 <http://www.kommersant.ru/doc/2723416>.

${ }^{70}$ Irina Sukhanova, 'Kseniia Sobchak snialas' v bikini tsvetov georgievskoi lentochki' (Kseniia Sobchak Photographed in a Bikini in the Colours of the St George ribbon), Komsomol'skaiaPravda, 16 April $2015<$ http://www.kp.ru/daily/26368.4/3248978/>. Sobchak posted another somewhat more decorous picture of herself on Instagram in an orangeand-black striped summer dress. See <https://instagram.com/p/2b4JGViCIG/?takenby=xenia_sobchak $>$. In the accompanying text she claimed that 'over the last two years the 
However, the wrath of bigots has also descended upon inoffensive minors who involuntarily attracted attention. In April 2015, a video clip of some dancing schoolgirls in Orenburg created a nationwide scandal. They were dressed up as bees that chased away Winnie the Pooh and saved their honey, but someone concluded that they were not only making indecent movements with the lower parts of their bodies - so-called twerking their costumes were even sewn of orange-and-black striped cloth. ${ }^{71}$ The local state prosecutor took responsibility and opened an investigation into the matter. ${ }^{72}$ However, at this point some bona fide patriots concluded that the moral panic of the ribbon sticklers themselves threatened to turn the St George action into a farce. High-profile nationalist Egor Kholmogorov reminded the public that the natural colours of bees are in fact orange and black. ${ }^{73}$ In the end, the case was closed without anyone receiving administrative punishment. ${ }^{74}$

\section{Tying the ribbon to the state juggernaut}

In any case, the most serious threat to the unifying potential of the St George ribbon campaign has emanated not from greedy businessmen or overzealous enthusiasts, but from the state authorities themselves. Officially, the action should be not only non-profit, but emphatically also non-political. ${ }^{75}$ However, in Russia the concept of 'political' is somewhat peculiar: it pertains to oppositional politics and party politics only. The actions of the state authorities are not regarded as 'political': what they do is 'statecraft'. The state could not and should not stay out

St George ribbon has become a symbol of more than I would like to see'. But, she added, 'it's not important how the propagandists are using this very important symbol. What is important to me is that this is not a symbol OF THAT HELL which these rascals are trying to tie it to, but a symbol of the Victory over fascism'.

71 'Iunie "pchelki v georgievskikh lentakh" ispolnili eroticheskii tanets' (Young 'Bees in St George Ribbons' Perform an Erotic Dance), Moskovskii komsomolets, 13 April 2015 $<$ http://www.mk.ru/print/article/1206505/>.

${ }^{72}$ Aleksandr Boiko, 'Sledstvennyi komitet usmotrel razvrat v tantse orenburgskikh "pchelok" (The Investigating Committee Looked into the Lewdness in the Dance of the 'Bees' in Orenburg), Komsomol'skaia Pravda, 14 April $2015<$ http://www.kp.ru/ daily/26366/3247977/>.

73 'Publitsist Egor Kholmogorov - o posledstviiakh kotorye sleduiut za arkhaizatsiei natsional'noi massovoi kul'tury' (Publicist Egor Kholmogorov on the Consequences that Follow from an Archaization of the National Mass Culture), Izvestiia, 16 April $2015<\mathrm{http}$ :// izvestia.ru/news/585507\#ixzz3juNH89oh>.

74 'SK otkazalsia vozbuzhdat' delo posle tantsa "pchelok" v Orenburgskoi oblasti' (The Investigating Committee [i.e. the State Prosecutor] Refused to Press Charges after the Dance of 'The Bees' in the Orenburg Oblast), Gazeta.ru, 18 May $2015<$ http://www.gazeta. $\mathrm{ru} /$ social/news/2015/05/18/n_7204533.shtml $>$.

${ }^{75}$ Kodeks aktsii: 'Georgievskaia lentochka'<http://glgmay.ru/about/codex>. 
of the ribbon campaign: the authorities have assisted the organizers in various ways - and have themselves been helped by the action, no doubt a major motivation. Thus, the official organ of the Russian government Rossiiskaia gazeta - explained to its readers that the 'St George action is non-political' but in the very same article also reported that the ribbons were disseminated abroad with the active assistance of Russian embassies and diplomatic personnel. ${ }^{76}$ As a Foreign Ministry spokesperson explained, 'the preservation of historical memory is one of the vectors of our foreign policy [...]. Therefore we provide support for this symbolic action.? ${ }^{7}$

The link between the authorities and the ribbon of St George is more than a matter of the regime lending a helping hand in the action. Tanks and other military vehicles adorned with orange and black stripes symbolize the military power of the contemporary Russian state just as much or more than they commemorate the war (see fig. 11).

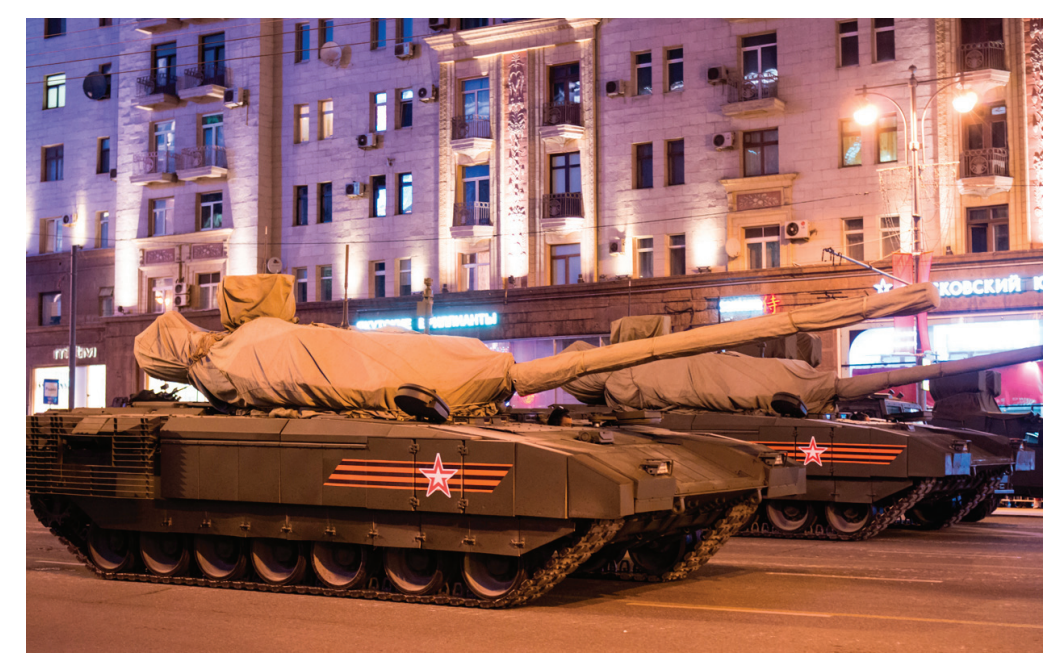

Fig. 11. Decorated tanks. Rehearsal of the Victory Day parade at Tverskaia street, Moscow, with new Russian military vehicles. @ Mikhail Varentsov / Shutterstock.com

Increasingly, the ribbon has become a symbol not only of patriotism and of honouring the veterans of the Great Fatherland War, but also

${ }^{76} \mathrm{Natal}$ 'ia Ivanovskaia, 'Ia pomniu, ia gorzhus': Georgievskie lentochki vnov' opoiasali Mir' (I Remember and I'm Proud: St George Ribbons Once Again Girdle the World), Rossiiskaia gazeta, 24 April $2012<$ http://m.rg.ru/2012/o4/23/georg-site.html>.

77 Arkadii Kolybalov, 'Lentochka vidna iz kosmosa' (The Ribbon Can be Seen from Space), Rossiiskaia gazeta, 22 April 2015 <http://www.rg.ru/2015/04/22/lentochka-site.html>. 
of supporting the Putin regime. The slide towards such politicization became particularly acute in 2015, with accounts of state employees in the provinces who were threatened with dismissal unless they wore the St George ribbon, and of pupils reported to the police because they came to school without it. ${ }^{78}$ In May 2015, journalist Anton Orekh in Ekho Moskvy opined that the St George ribbon had originally been a brilliant idea. In the first years, it was worn mainly by young people chanting, 'I remember, I'm proud', and it all seemed very sincere. However,

the celebration has become increasingly bureaucratic and lifeless, and the man in the street is almost indifferent to it [...]. The ribbon has become a code symbol for devotion to the authorities and the president. And even if his ratings have reached cosmic heights, I see far fewer ribbons in the streets now that I did even as recently as last year. ${ }^{79}$

Orekh's observation of a decreasing number of ribbons on public display may or may not be correct - other Russians would probably dispute it. However, it does point to an inherent dilemma for the Putin regime. As argued above, it has been essential to present the action as a civil society initiative, and not just another campaign foisted upon society from above. Only if it is perceived as an expression of independent, sincere and voluntary support can it provide the regime with legitimacy. But in authoritarian societies, genuinely independent support is difficult to sustain.

A brief excursion into the parallel phenomenon of the 'Immortal Regiment' can illustrate this point. Just like the ribbon of St George, the 'Immortal Regiment' is a recently invented tradition, and is similarly claimed to have emanated from outside the corridors of power. However, while in the case of the St George ribbon this claim rests on somewhat shaky ground, few will deny that the immortal regiment initially was a genuine grassroots undertaking. The tradition originated in 2012 in the Siberian city of Tomsk on the initiative of some journalists from a local TV station, TV-2, which at the time was not only independent but also regarded as clearly oppositional (later, the station was taken over by regime-loyal owners). ${ }^{80}$ As with the St George action, the bylaws of the

${ }^{78}$ Vishnevskii, 'Ot simvola edinstva'.

79 Anton Orekh, 'Tabel' o rangakh', Ekho Moskvy, 10 May $2015<$ http://m.echo.msk.ru/ interview/detail.php? $\mathrm{ID}=1546152>$.

${ }^{80}$ See Andrei Okara, 'Den' pobedy kak informatsionnaia duel' Moskvy i Kieva' (Victory Day as an Informational Duel between Moscow and Kiev), Ekho Moskvy, 21 May 2015 <http://echo.msk.ru/blog/okara/1552514-echo/>. In an alternative version, the march was five years older, and originated with a pensioner in the city of Tiumen', Gennadii Ivanov, 
Regiment state that it is 'non-commercial and non-political'; further, it is 'a nongovernmental, civil society initiative', and finally: 'The Regiment cannot be personalized by any one individual, not even the most respected. ${ }^{81}$ This seems to be a rather transparent reference to Putin, and a warning to the authorities not to try to take over the enterprise.

The 'regiment' consists of columns of people who walk down one of the main thoroughfares of a city carrying photographs of their loved ones who fought in the Great Fatherland War. ${ }^{82}$ Superficially, the event may give associations of Soviet-era parades when pictures of Marx, Lenin and Stalin were carried in solemn procession on 1 May and 7 November. This, however, is probably not the most relevant parallel. Importantly, the photographs carried in the 'regiment' marches do not represent 'the powers', but a relative of the participants themselves. Therefore, a funeral cortege or a church procession seem to be more apt comparisons.

Due to its semi-private character, the 'Immortal Regiment' has been less susceptible than the St George ribbon campaign to attempts of a 'hostile takeover' from the side of the authorities. Even so, an urge to do so apparently seems to linger among Putin ideologists. The influential pro-Kremlin journalist Nikolai Starikov, for instance, writing on his LiveJournal blog, deplored that instead of celebrating this day as a day of unity and Victory, it is developing into millions of instances of private mourning. ${ }^{83}$ Therefore, in Starikov's view, the Regiment march does not serve to bolster state patriotism sufficiently.

The 2015 Immortal Regiment was a spectacular success, surpassing all prognoses. On Victory Day, according to various estimates, between 350,000 and 500,000 people participated in Moscow, ${ }^{84}$ more than double or treble the number that had originally signed up (see fig. 12). ${ }^{85} \mathrm{~A}$ total of

who organized what he called 'A parade of victors'. See Viktoriia Grishina, “"Bessmertnyi polk” pridumal tiumenskii pensioner' (The Immortal Regiment was Invented by a Pensioner from Tiumen'), Komsomol'skaia Pravda, 11 May $2015<$ http://www.kp.ru/online/ news/2051662/>. Ivanov claims that the idea came to him in a dream. Apparently, his original initiative petered out, and the Immortal Regiment was reinvented five years later.

81 'Ustav polka' (Bylaws of the Regiment) <http://moypolk.ru/ustav-polka>.

${ }^{82}$ It is not necessary that they died in the war.

${ }^{83}$ Nikolai Starikov, 'Vedet li Bessmertnyi polk k bessmertiu Pobedy' (Will the Immortal Regiment Lead to Immortality for the Victory?) 8 April $2015<$ http://nstarikov.ru/blog/50518>.

84 'V aktsii "Bessmertnyi polk" v Moskve priniali uchastie ne menee 350 tysiach chelovek' (At Least 350,00o People Participate in the Immortal Regiment Action in Moscow), Ekho Moskvy, 9 May $2015<$ http://echo.msk.ru/news/1545576-echo.html?=top>.

85 'Okolo 150 tys. chelovek primut uchastie v aktsii "Bessmertnyi polk - Moskva' (Roughly 150,00o People to Take Part in the 'Immortal Regiment' Action in Moscow), TASS, 28 April $2015<$ http://tass.ru/obschestvo/1937498>. The year before, only 40,00o people had participated in Moscow. See Liubov' Protsenko, 'Bolee 110 tysiach moskvichei 


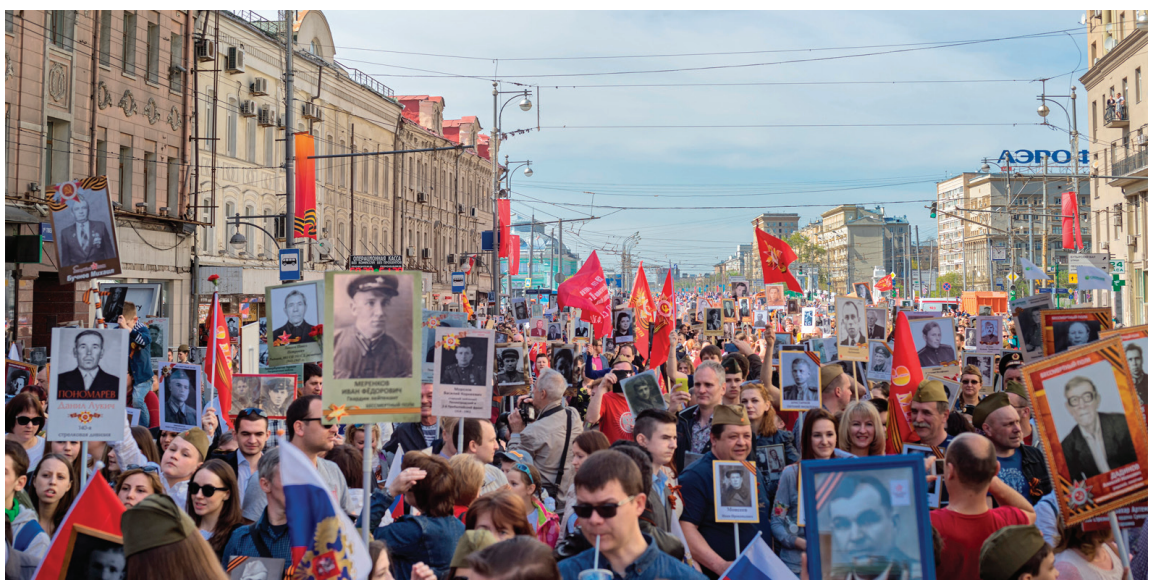

Fig. 12. Immortal Regiment marches on. Moscow celebrates 7oth Victory Day anniversary on May 9, 2015. ๑ Alexander Kuguchin / Shutterstock.com

12 million people participated in 120 different Russian towns and cities, in addition to marches organized abroad. ${ }^{86} \mathrm{~A}$ few critical voices denounced the march as 'a cynical, coarse propaganda parade, ${ }^{87}$ and a week after the March a number of photos were published on the internet, showing heaps of discarded Regiment placards near public garbage cans. Allegedly, this showed that participants in the marches had been paid to carry portraits of people they did not know and did not care about, and therefore disposed of the placards unceremoniously as soon as the march was finished. On the other hand, Oleg Lur'e, a former journalist of Novaia Gazeta, speculated that the photos were fake and the entire story a hoax, intended to discredit the Regiment. The placards, he believed, had probably been produced after the march by the same people who posted the photos on the internet. ${ }^{88}$ In some cases, however, the explanation turned out to be rather mundane: some local organizers of the Immortal Regiment marches had with the best intentions produced placards of veterans who had no surviving relatives and handed them out to people who wanted to participate in the march but

zapisalos' na aktsiiu "Bessmertnyi polk"' (More Than 110,ooo Muscovites Have Signed Up for the 'Immortal Regiment' Action), 22 April 2015 <http://m.rg.ru/2015/04/22/polk-site. html>.

${ }^{86}$ Anatolii Zhdanov, “'Bessmertnyi polk' ne khochet v shtat' (The Immortal Regiment Does Not Want to Become Part of the Establishment), Kommersant <http://kommersant. $\mathrm{ru} / \mathrm{doc} / 2736209>$.

${ }^{87}$ See, for example, Aleksei Mel'nikov, 'Prizrachnyi polk' (A Regiment of Ghosts), Ekho Moskvy, 9 May $2015<$ http://aleks-melnikov.livejournal.com/317210.html>.

${ }^{88}$ Oleg Lur'e, “'Bessmertnyi polk”. Tekhnologiia feikov i bol'shie den'gi', Ekho Moskvy, 11 May $2015<$ http://oleglurie-new.livejournal.com/246039.html>. 
had no relatives who fought in the war. After the march, nobody had made sure that these photos were collected and discarded properly. ${ }^{89}$ However, in some other cases the origin of some of these portrait piles remained obscure, and the chairman of the interregional council of the Immortal Regiment, Sergei Lapenkov, reported them to the local public prosecutor. Interestingly, he argued that the discarded photos might qualify as a violation against the Russian penal code 'since the St George ribbon is depicted on them'. ${ }^{\circ}$ Evidently, while the photos themselves were 'private' and abuse of them of no concern to the state, the ribbon is official and desecration of it is regarded as a far more serious matter: indeed, an offence against the state.

In any case, most commentators - also from the anti-Putin opposition - accepted the marches as genuine expressions of affectionate memory. In Ekho Moskvy, Anton Orekh remarked, 'personally, I have no doubts about the sincerity of "The Immortal Regiment". This is very different from the Putin rallies to which the multitudes are ushered or bused in'. ${ }^{91}$ However, just as the St George ribbon in his view had become the symbol of 'hysterical semi-officialdom [ofitsioz]', he feared something similar could happen with the Regiment.

These apprehensions were not totally unfounded. In 2015, the Moscow march ended for the first time at Red Square, perhaps the most potent architectural symbol of Russian state power. ${ }^{92}$ Here, marchers were met by Vladimir Putin, who walked with them for the final steps, carrying a photograph of his father (see fig. 13). In an interview with Russian TV, Putin emphasized that the initiative to the march 'was born not in offices or in administrative structures, but in the hearts of people. ${ }^{93}$ This seemed to send the message that he would respect the independence of this civil initiative, but the original Tomsk organizers were apparently not reassured. In May 2015 they sent a letter to President Putin personally, expressing

89 'Foto s vybroshennymi plakatami "Bessmertnogo polka" v Priamur'e ob"iasnili nedorabotkoi koordinatorov' (Coordinators' Mistake Explains Photos of Discarded Placards from the Immortal Regiment in Amur), Interfaks, 14 May $2015<$ http:// www.interfax.ru/russia/441747>; Azat Bilalutdinov, 'Die Gedenkinitiative "Unsterbliches Regiment" zwischen Gesellschaft und Politik', in Mischa Gabowitsch, Cordula Gdaniec and Ekaterina Makhotina (eds), Kriegsgedenken als Event. Der 9. Mai 2015 im postsozialistischen Europa, Paderborn, 2016.

90 'Sozdateli "Bessmertnogo polka" obratilis' v prokuratoru iz-za fotografii s vybroshennymi plakatami' (The Creators of the 'Immortal Regiment' Parade ask Prosecutors to Examine Discarded Placards), Interfaks, 12 May $2015<\mathrm{http}$ ://www.interfax. $\mathrm{ru} / \mathrm{russia} / 441228>$.

${ }^{91}$ Orekh, 'Tabel' o rangakh'.

${ }^{92}$ Liubov' Protsenko, 'Bolee'.

93 'Vladimir Putin prinial uchastie v aktsii “Bessmertnyi polk"' (Vladimir Putin Took Part in the Immortal Regiment Parade) <https://www.youtube.com/watch? $=\mathrm{S}_{40 \mathrm{OMzVhNa}} \mathrm{O}>$. 
concerns that the All-Russian Popular Front, a 'GONGO'94 established in 2011 at the behest of Putin himself, was trying to take their organization under its umbrella and indeed to control it. ${ }^{95}$

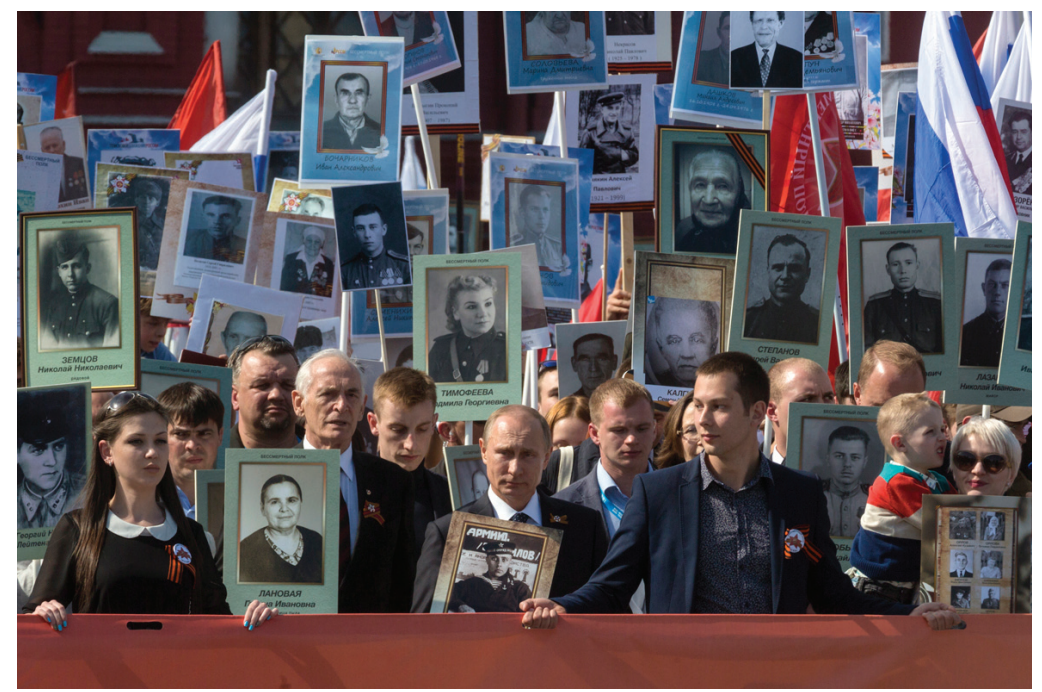

Fig. 13. Russian President Vladimir Putin (centre) holds a portrait of his father as he takes part in the Immortal Regiment march during the Victory

Day celebrations in Moscow on May 9, 2015. ( ) Nickolay Vinokurov / Shutterstock.com.

The new war that changed everything

When Stephen Norris reported on the 65th Victory celebrations in Russia in 2010, his analysis focused on the widespread concern across the country that the commemoration was threatened by distasteful business exploitation. ${ }^{96}$ By 2015, the commercial issue had moved into the background: the major controversy now concerned the intimate connection between the victory celebrations and support for the Putinist regime. The intervening factors, which had turned not only domestic Russian politics upside-down, but also the relationship between Russia and the outside world, were the annexation of Crimea and the war in Eastern Ukraine. Victory Day is celebrated perhaps even more intensely in Crimea than in Russia proper (see fig. 14).

${ }^{94} \mathrm{GONGO}=$ government-organized nongovernmental organization.

95 Kozlov and Korchenkova, “Bessmertnyi polk” ne khochet'.

${ }^{96}$ Stephen M. Norris, 'Memory for Sale: Victory Day 2010 and Russian Remembrance', Soviet and Post-Soviet Review, 38, 2011, pp. 201-29. 


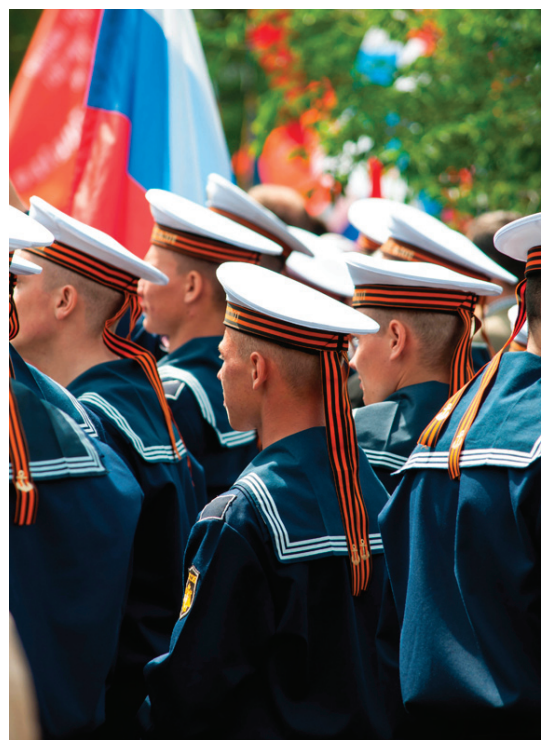

Fig. 14. Celebrating the 69th anniversary of the Victory Day and 7oth anniversary of Sevastopol liberation from fascists. Sevastopol 2014.

Seamen. ( ) Jiinna / Shutterstock.com.

Ever since the 'little green men' took over the peninsula, posters and billboards decorated in orange and black stripes have cropped up in towns and hamlets throughout this new Russian Federation subject. The ribbon of St George has become an emblem of Russian triumphalism. ${ }^{97}$ In the selfproclaimed Donetsk and Lugansk People's Republics, it is the main banner, featured in abundance on official websites. Symptomatically, 'the hero of Sloviansk', Igor Strelkov-Girkin, and his girlfriend are shown on the Internet in outfits made of rather garish orange and black-striped material (fig. 15)..$^{98}$ The Donetsk People's Republic has also instituted an order of valour for militiamen who have distinguished themselves in the ongoing war (fig. 16). ${ }^{99}$

97 Aleksandr Gornyi, 'Simferopol'-Sevastopol'. Atmosfera Pobedy' (Simferopol'Sebastopol: An Atmosphere of Victory), 9 May 2015, Ekho Moskvy <http://m.echo.msk.ru/ blogs/detail.php? ID =1545560>.

98 Viktoriia Novikova, 'Igor' Strelkov zhenilsia na grazhdanke Ukrainy' (Igor' Strelkov Married a Citizen of Ukraine) <http://www.spr.ru/novosti/2014-12/igor-strelkovzhenilsya-na-grazhdanke-ukraini.html $>$.

99 'Gosudarstvennye nagrady DNR' (The State Awards DNI), Novorossiia <http:// novopressa.ru/articles-57.html>. 
THE ST GEORGE RIBBON IN RUSSIAN NATION-BUILDING 687

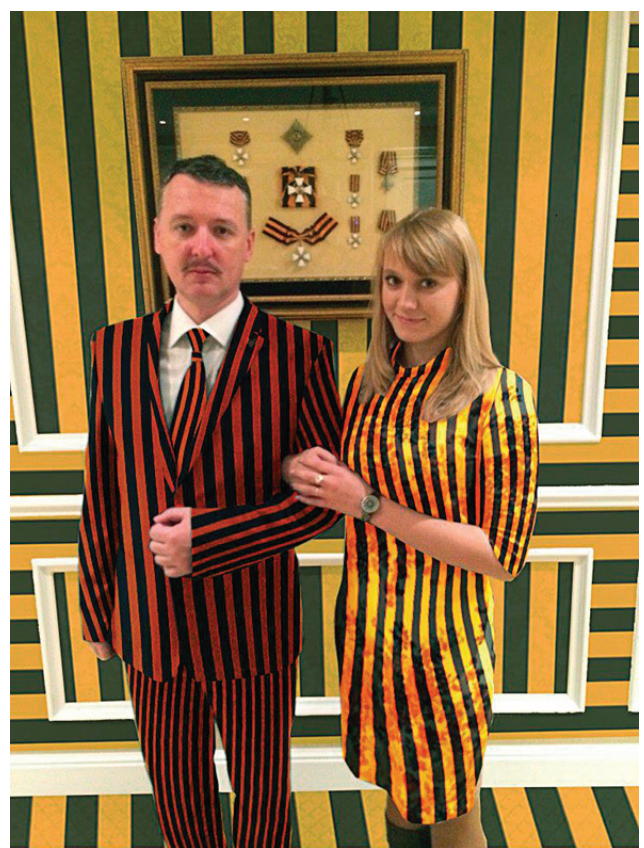

Fig. 15. Galereia S.ART. All rights reserved.

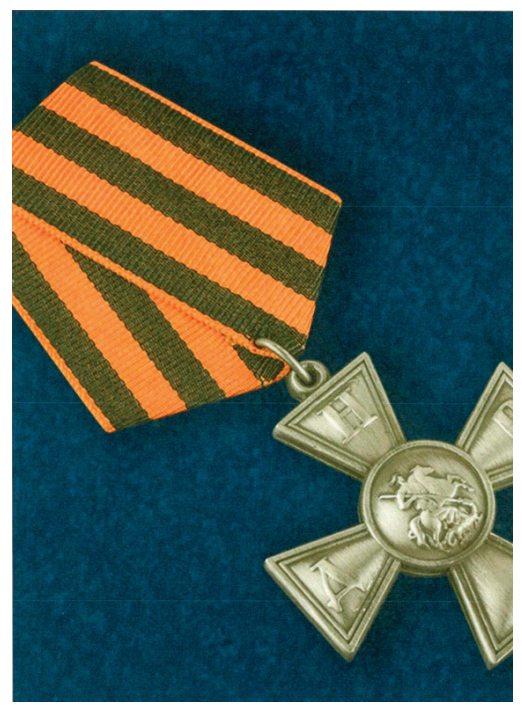

Fig. 16. Galereia S.ART. All rights reserved. 
In Kommersant, journalist Elizaveta Surnacheva remarked that in 2014 the St George ribbon 'became a symbol not only of the victory in 1945: precisely with this symbol Crimea was returned to Russia and war is being fought in southeast Ukraine. ${ }^{100}$ Iuliia Latynina mused: 'in which war is the St George ribbon actually a victory symbol? The only war which I know to have been fought under the black and orange flag is the undeclared war in Donbas. ${ }^{101}$ Also in Kiev-controlled Ukraine there were deep feelings of a close connection between the St George symbol and the Donbass rebel cause. Somewhat disingenuously the ribbon is often portrayed as a fascist symbol - since it had also been used by the antiSoviet Russian Liberation Army. A huge billboard outside L'viv in western Ukraine showed a St George ribbon arranged as a swastika (fig. 17).

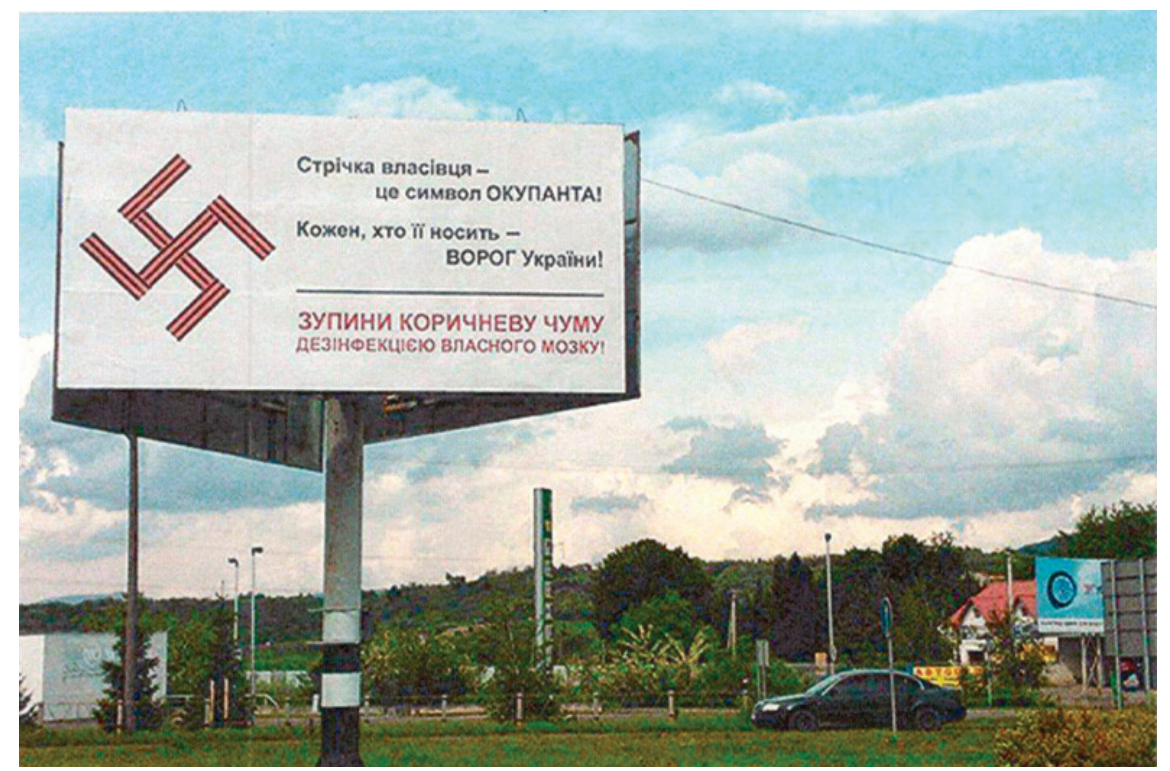

Fig. 17. 'The Vlasovite ribbon is a symbol of the occupier. Everyone who carries it is an enemy of Ukraine.' Galereia S.ART. All rights reserved.

In December 2014, an exhibition in Kiev of 'the hundred best patriotic posters' showed several images where the ribbon was associated with fascism (see fig. 18). ${ }^{102}$ Even the serious daily, Zerkalo Nedeli, reporting on

100 Surnacheva, 'Lentochnyi konveier'.

${ }^{101}$ Iuliia Latynina, 'Kod dostupa'.

102 'Ubei "kolorada"! - v Kieve otkrylas' vystavka "10o luchshikh patrioticheskikh plakatov"' (Kill a 'Colorado Beetle'! In Kiev an Exhibition of the Hundred Best Patriotic 


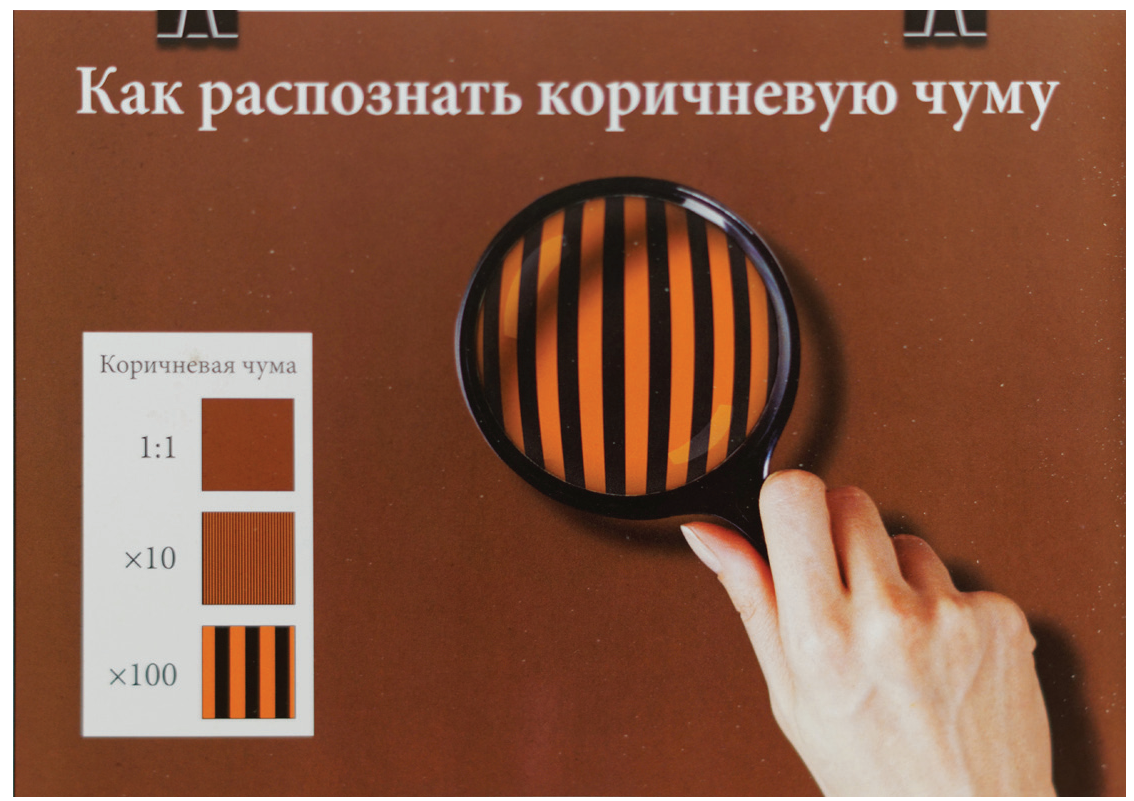

Fig. 18. 'How to recognize the brown plague.' Photo by V. V. Mihailov, copyright Politnavigator News Agency <http://politnavigator.net>.

a pro-Russian rally in Kharkiv in May 2014, claimed that the demonstrators carried 'Nazi symbols'. To substantiate this startling piece of news, it explained that the demonstrators 'held in their hands the orange-black flag, which was used by General Vlasov's Russian Liberation Army when fighting on the side of Hitler during the Second World War. ${ }^{103}$

The insurgents - and by extension, everyone sympathizing with them - are in Ukraine regularly referred to as 'Colorado beetles' - kolorady. ${ }^{104}$ This contemptuous moniker, which reduces the enemy to harmful insects, is based on the fact that this beetle, known to invade gardens and destroy food crops, has orange and black stripes.

Posters has Opened) <http://www.politnavigator.net/ne-prokhodi-mimo-ubejj-kolorada-vkieve-otkrylas-vystavka-10o-luchshikh-patrioticheskikh-plakatov-foto.html>.

103 'Kruglyi stol natsional'nogo edinstva v Khar'kove piketiruiut liudi s vlasovskimi flagami' (A Roundtable of National Unity in Kharkiv is being Picketed by People with Vlasov Flags), Zerkalo nedeli, 17 May 2014 <http://zn.ua/UKRAINE/kruglyy-stol-nacionalnogoedinstva-v-harkove-piketiruyut-lyudi-s-vlasovskimi-flagami-145262_html>.

104 See, for instance, 'V Khar'kove proizoshla potasovka mezhdu Maidanom i Antimaidanom', Zerkalo nedeli (Fight in Kharkiv between Maidan and Anti-Maidan Factions), 13 July $2014<$ http://zn.ua/UKRAINE/v-harkove-proizoshla-potasovka-mezhdumaydanom-i-antimaydanom-148883_html>; Oleg Pokal'chuk, 'Voina liudei' (War Among People), Zerkalo nedeli, 22 May $2014<$ http://gazeta.zn.ua/socium/voyna-lyudey-1-_html>. 
Just as the real Colorado beetles should be ruthlessly exterminated, no mercy ought to be shown towards the human kolorady (fig. 19).

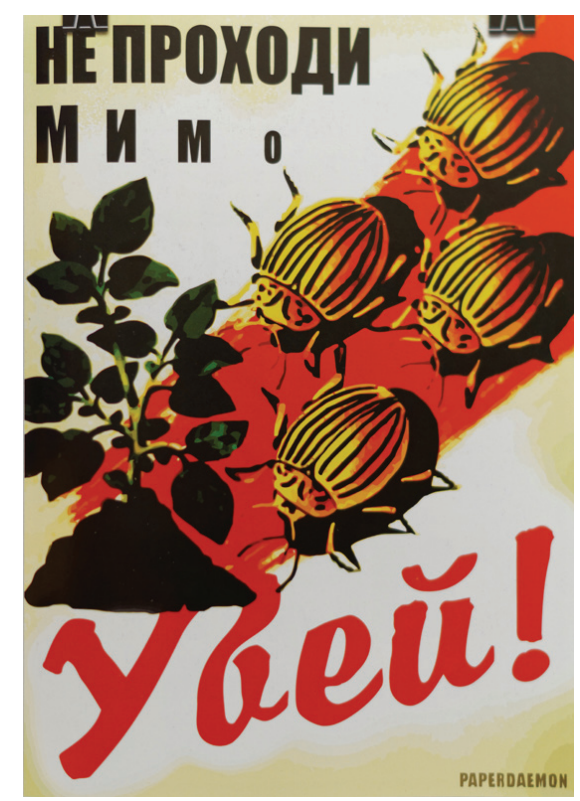

Fig. 19. Photo by V. V. Mihailov,

copyright Politnavigator News Agency $<$ http://politnavigator.net $>$.

When pro-Russian and pro-Ukrainian activists clashed in Odessa on 2 May 2014, a fire broke out as the pro-Russians sought shelter inside the city's trade union building. More than forty people perished, while, according to the New York Times, demonstrators outside chanted 'burn, kolorady, burn!' ${ }^{105}$ The impression this tragedy made on the Russian public can hardly be exaggerated. The dehumanizing connotations of the kolorady epithet were regarded as conclusive proof of the callousness of Ukrainian nationalists. In fact, however, this odious label was apparently concocted in Russia by anti-Putin oppositionists, and then exported to Ukraine. ${ }^{106}$ Also, some of the most insulting anti-Russian posters at the

105 Andrew E. Kramer, 'Ukraine's Reins Weaken as Chaos Spreads', New York Times, 4 May 2014 <http://www.nytimes.com/2014/05/05/world/europe/kievs-reins-weakenas-chaos-spreads.html>. See also, Richard Sakwa, Frontline Ukraine: Crisis in the Borderlands, London, 2015, pp. 97-99; Pål Kolstø, 'Crimea vs. Donbas: How Putin Won Russian Nationalist Support — and Lost it Again’, Slavic Review, 76, 2016, 3 (forthcoming).

${ }^{106}$ In an interview with the radio station Ekho Moskvy, diehard anti-Putin oppositionist Konstantin Borovoi claimed authorship of the expression, together with his close 
exhibition of 'patriotic art' in Kiev were produced by a Russian artist from Perm', who later sought political asylum in Ukraine. ${ }^{107}$

\section{Uniting the Russian nation - and isolating the Russian state}

Russian oppositionists hold that the politicization of the St George ribbon divides the Russian nation. In May 2015 Boris Vishnevskii claimed that, 'no perfidious enemy could have changed the perception of the symbol of Russian military honour more mercilessly than the Russian authorities themselves have done over the last year'. ${ }^{108}$ The St George ribbon has become 'a badge of belonging to the Putinite majority', ${ }^{109}$ a 'litmus test of loyalty', and for that reason produces societal schism (raskol). ${ }^{110}$ Liberals point out that the ribbon is used as a sign of recognition among participants in pro-regime flash-mobs attacking opposition rallies. ${ }^{111}$

According to an unsigned editorial in Nezavisimaia gazeta in April 2015:

The black and orange has become an attribute to rallies against 'fifth columnists' and liberals. This is something new. Now the citizen is pushed towards a position where he, along with the memory of the war, also accepts a very concrete political programme, specifically, a stigmatization of the West and Kiev. If he does not do that, and remains, for instance, a liberal, a Westernizer, opposed to the annexation of Crimea, then that means that he has not taken on board the lessons of the war, that he is not worthy of the feats of our fathers and grandfathers. ${ }^{112}$

These observations are no doubt correct, as far as they go. The St George ribbon does indeed divide the Russian nation - or rather, it reinforces and cements divisions that have been opening up in recent years since the

collaborator, Valeriia Novodvorskaia. 'Bez durakov' (Without Fools), Ekho Moskvy, 9 May 2015 <http://echo.msk.ru/programs/korzun/1544308-echo/>.

107 'Avtor plakata "Ubei kolorada!" poprosit ubezhishche na Ukraine' (Creator of the Poster 'Kill a Colorado' to Seek Asylum in Ukraine), Vpered, Rossia! <http://вперёдроссия. p $\$ /$ blog/43967517248/Avtor-plakata-\%22Ubey-kolorada!\%22-poprosit-ubezhischa-naUkrayine>; 'Permskii khudozhnik uekhal v Ukrainu iz-za dela ob ekstremizme' (Artist from Perm' Moved to Ukraine Due to Extremism Case), Novaia gazeta, 12 December 2014.

${ }^{108}$ Vishnevskii, 'Ot simvola edinstva'.

${ }^{109}$ Okara, 'Den' pobedy'.

110 Interview with Gennadii Bordiugov in Ekho Moskvy, 2 May 2015: 'Kak sokhranit' podlinnyi den'pobedy' (Preserve the Genuine Victory Day) <http://echo.msk.ru/ programs/victory/1540158-echo/>.

${ }^{111}$ Andrei Pozniakov, 'Georgievskie lenty v kazhdyi dom?' (St George Ribbons to Every Home?), Ekho Moskvy, 6 May 2015 <http://echo.msk.ru/blog/shoo_ash/1543526-echo/>.

112 'Velikaia Pobeda: deistvitel'no odna'. 
massive anti-government demonstrations in Moscow and other Russian cities in the winter of 2011/12 and Putin's harsh clampdown. Interestingly, during these demonstrations a ribbon was the main symbol, and also at this time when the choice of colour was determined by a desire to unify ideologically disparate elements. In the demonstrations, nationalists, leftists and liberals marched under their own flags: black-gold-white for the nationalists; red for the leftists and white-blue-red for the Westernizing liberals. To signal unity among them, the organizers came upon the idea of a white ribbon - white allegedly being 'the sum of all colours'. ${ }^{113}$

Vladimir Putin attempted to discredit the demonstrators by comparing their white ribbon with a condom, ${ }^{114}$ but the sarcasm backfired on him: the oppositionists turned up in the next demonstration with placards proudly declaring that, in contrast to the president, they knew the difference between a ribbon and a contraceptive. Even so, it is safe to say that in the duel between the orange-black and white ribbons, the former has carried the day. The nation is not split into two halves of equal size, for and against Putin. Opinion polls show that the overwhelming majority of the population support the St George ribbon campaign and have warm feelings towards it. Rossiiskaia gazeta reported in 2013 that while among people of twenty-four years and younger, 62 per cent approved unequivocally of the campaign. Among those of forty-five years and older, this figure rose to 74 per cent. Roughly 12 per cent of those interviewed had negative attitudes towards the ribbon; among them, only half were 'categorically' against it. ${ }^{115}$

A poll from 2015 from the highly respected Levada Institute showed that as many as 85 per cent had watched the Victory Parade on Red Square on 9 May; 78 per cent liked it, a mere 5 per cent did not. Only 6 per cent of the respondents were unaware of the 'Immortal Regiment' phenomenon; no more than 3 per cent had a negative opinion of it. The vast majority,

113 Aleksei Ovchinnikov, 'Tsoi pel, OMON ulybalsia, Bolotnaia likovala: Miting protesta na Bolotnoi ploshchadi v Moskve sobral okolo 50 tysiach chelovek' (Tsoi Sang While the Riot Police Smiled and Rejoiced: Protest Rally in Moscow's Bolotnaia Square in Moscow Attended by 50 Thousand), Komsomol'skaia pravda, 10 December $2011<\mathrm{http}: / / \mathrm{m}$. spb.kp.ru/daily/25802/2783071/>; Pål Kolstø, 'Marriage of Convenience? Collaboration between Nationalists and Liberals in the Russian Opposition, 2011-2012', Russian Review, 75, October 2016, pp. 645-63.

${ }^{114}$ See video, “A ia dumal eto kontratseptivy...". Putin o rossiiskom simvole protesta - beloi lente' (I Thought They Were Contraceptives: Putin on the Russian White Ribbon Protest Symbol), at Tsenzor.net <http://censor.net.ua/video_news/191395/a_ya_dumal_ eto_kontratseptivy_putin_o_rossiyiskom_simvole_protesta_beloyi_lente_video>.

${ }^{115}$ Ekatarina Dobrynina, 'Rossiianam nravitsia aktsiia "Georgievskaia lentochka"' (Russians Like the St George Ribbon Campaign) 2 May 2013 <http://www.rg.ru/2013/05/o2/ lentochka-site.html>. 
89 per cent, were positive. ${ }^{116}$ Another survey from 2014 reported by Kommersant showed that a staggering 94 per cent of those interviewed appreciated the St George ribbon, 82 per cent 'with no qualifications'. Valerii Fedorov, director-general of the (relatively pro-government) polling institute VTSIOM, pointed out that 82 per cent was remarkably similar to the popularity levels recorded for Vladimir Putin after the Crimean annexation. In Fedorov's view, this was no coincidence: 'with Putin's 84 per cent popularity ratings, the correlation of forces between the pro-ribbon and the anti-ribbon people could be quite easily predicted. ${ }^{117}$

Assuming that the polling data is basically correct, ${ }^{118}$ the Putin regime seems to have won acceptance among the populace for the view that the St George ribbon campaign is a genuine expression of pride in Russia's victory in the Second World War, and that the current powerholders in the Kremlin are the legitimate custodians of this honourable legacy. Supporting the ribbon and supporting Putin are two sides of the same coin, and those who distance themselves from the St George ribbon campaign should be ostracized from the Russian nation. Furthermore, it can be argued that, by their vehement reactions against the St George ribbon, some oppositionists are themselves contributing to this ostracism. They not only attack the regime, but also taunt ordinary Russians who participate in the campaign. For instance, Andrei Pozniakov writes, 'in the current situation, to put on the St George ribbon for the sake of the celebration is very much like wearing a swastika after a series of Jewish pogroms, and arguing that this is a sign of the sun, summer and light.. ${ }^{119}$ Besides being somewhat farfetched, the comparison is unlikely to boost recruitment to the anti-ribbon camp. Similarly, Sergei Zaporozhskii claims that the whistling and dancing of grandchildren whose grandfathers fought in the war reminded him of 'a witches' Sabbath of brainless demons'. Further, 'their billboards with St George ribbons and patriotic inscriptions often contain grammatical errors.' ${ }^{120}$ Such attempts to show that 'we of the opposition are better

116 'Sdvig v storonu gordosti i paradnosti. Kak s godami izmenilsia pervonachal'nyi smysl Dnia Pobedy' (Moving Closer to Pride and Parades: How the Original Meaning of Victory Day has Changed Over the Years), 20 April 2015<http://lenta.ru/articles/2015/04/20/ denpobedy/>.

117 Surnacheva, 'Lentochnyi konveier'.

118 Some respondents may have thought it safer or more convenient to respond in a way they assumed the pollsters would like, a common methodological problem with opinion polls even in democratic countries (cf. the so-called 'Bradley effect').

119 Pozniakov, 'Georgievskie lenty'.

${ }^{120}$ Sergei Zaporozhskii, 'U chertei svoi den' Pobedy' (The Demons have Their Own Victory Day), Ekho Moskvy, 7 May 2015 <http://m.echo.msk.ru/blogs/detail.php?ID=1544356>. 
educated and more cultured than you' will inevitably only serve to drive the anti-Putin opposition deeper into isolation.

During his two first presidential periods, Putin clearly tried to appeal to as many segments of the Russian population as possible, also the proWestern and pro-democracy liberals. With his third period has come a major shift in Kremlin strategy. A new ideology of 'traditional values' has been concocted, including stringent opposition to homosexuality, with a flurry of new Draconian laws rushed through the parliament in the spring and summer of 2012, severely curtailing any kind of opposition activity. ${ }^{121}$ The Putin regime had clearly concluded that it could do without the support of the liberals who in any case were irredeemably lost for 'the national cause.. ${ }^{122}$ Trying to woo them back was futile, but they could be included in the nation-building strategy in another way, as an internal enemy and a contrast fluid.

However, while the St George ribbon campaign can be said to have had the desired effects within Russia, the same cannot be said about its fallout abroad, particularly not in the other former Soviet republics. Also here, the same message that resonates within Russia is received loud and clear: enthusiasm for the ribbon and support for the Putin regime amount to the same thing. For precisely this reason, attempts are being made throughout the post-Soviet space to curtail or even prohibit public display of the ribbon.

For obvious reasons, opposition towards the St George ribbon has been most vociferous in Ukraine. ${ }^{123}$ In the Rada one legislator suggested that wearing the St George ribbon in public places should be banned by law. ${ }^{124}$ This proposal was apparently was never voted on, but local zealots took matters into their own hands. In L'viv, the Ukrainian weekly Vsia vlast' reported that a man was roughed up for wearing the ribbon. ${ }^{125}$ In Kharkiv, a policewoman was apparently dismissed from her job in February 2015 for

121 Geir Flikke, 'Resurgent Authoritarianism: The Case of Russia's New NGO Legislation', Post-Soviet Affairs, 2015, pp. 1-29.

${ }_{122}$ Henry Hale, 'How Nationalism and Machine Politics Mix in Russia', in Kolstø and Blakkisrud (eds), The New Russian Nationalism, pp. 221-48.

${ }^{123}$ Anastasiia Novikova, 'Kiev otkazhetsia ot georgievskoi lentochki kak simvol Dnia Pobedy' (Kiev Rejects the St George Ribbon as a Symbol of Victory Day), Komsomol'skaia Pravda, 6 May 2014; also in TASS, 6 May $2014<$ http://tass.ru/mezhdunarodnayapanorama/1168788>.

124 'V Radu vnesut zakonoproekt o zaprete publichnogo nosheniia georgievskoi lenty' (A Bill will be Presented to the Rada to Make it Illegal to Wear the St George Ribbon Publicly), Kommersant, 10 May $2015<$ http://vlasti.net/news/217300>.

125 'Vo L'vove izbili muzhchinu s georgievskoi lentoi' (In L'viv a Man with St George Ribbon was Beaten Up), Vsia vlast', 11 May $2015<$ http://www.vv.com.ua/news/90464>. 
pinning the St George symbol to her chest. ${ }^{126}$ When the press-secretary of the pro-European Ukrainian party UDAR burnt a ribbon on the Eternal Flame in Odessa in April 2014, it was officially denounced by a spokesperson of the Russian Foreign Ministry as 'a complete disparagement of historical memory.' ${ }^{127}$

A curious incident - but indicative of the increasingly jittery atmosphere in Ukraine - were the reactions when the April 2015 issue of the Ukrainian edition of the French fashion magazine Elle appeared on the streets, the front cover showing the American model Michelle Williams wearing an orange-and-black striped dress. Although the same cover had been used on the British edition of the magazine the month before, persistent rumours claimed that the Kremlin was behind this alleged Russian propaganda stunt. ${ }^{128}$ The French publishers were finally pressured to withdraw the issue and change the cover. ${ }^{129}$ Russian media gleefully reported on such incidents as proof of Ukrainian nationalist folly.

Attacks on the St George ribbon have occurred in virtually all of Russia's neighbour states. In May 2014, Russian actress Lidia Fedoseeva-Shukshina told reporters that when she had arrived at the Finnish border with a St George ribbon on her blouse, she had been exposed to a particularly thorough search. ${ }^{130}$ Crossing Russia's borders in either direction may often be a time-consuming affair, but this time the 'victim' felt that she had to tell about it at a press conference. In nearby Estonia, Russian veterans who tried to bring some dozen ribbons into the country had them confiscated at the border. ${ }^{131}$ An Estonian employee of the Norwegian oil company,

126 Mariia Gorelova, 'V Khar'kove sotrudnitsu militsii uvolili za georgievskuiu lentochku' (In Kharkiv a Policewoman with a St George Ribbon was Fired), Komsomol'skaia pravda, 24 February $2015<$ http://www.kp.ru/online/news/198317o/>.

${ }^{127}$ Anna Rakitina, 'Predali plameni. V Odese radikaly sozhgli georgievskuiu lentochku na Vechnom ogne' (Consigned to the Flames: In Odessa Radicals Burned St George Ribbons in the Eternal Flame), Rossiiskaia gazeta, 2 April $2014<\mathrm{http} / /$ m.rg.ru/2014/o4/o1/ lentochka.html>.

128 Natal'a Tubol'tseva, 'Oblozhka zhurnala "Elle” s plat'em tsvetov georgievskoi lenty vyzvala skandal na Ukraine' (The Cover of Elle with a Dress in the Colours of the St George Ribbon Creates Scandal in Ukraine), Komsomol'skaia pravda, 22 April 2015 $<$ http://www.kp.ru/daily/26370/3251319/>.

129 Nadezhda Ermolaeva, 'Ukrainskii Elle pomenial oblozhku nomera iz-za ugroz natsionalistov' (Ukrainian Elle Changed the Cover of One of Its Issues due to Nationalist Threats), Rossiiskaia gazeta, 24 April 2015 <http://www.rg.ru/2015/o4/24/elle-site-anons. html>.

130 'Georgievskaia lentochka Lidii Fedoseevoi-Shukshinoi vyzyvala allergiiu u finskikh pogranichnikov' (Lidiia Fedoseeva-Shukshina's St George’s Ribbon Causes Allergic Reaction among Finnish Border Guards), Komsomol'skaia pravda, 11 May $2014<$ http:// kompravda.eu/online/news/1734111>.

${ }^{131}$ Kseniia Akhmetzhanova, 'Na granitse s Estoniei u veteranov otobrali georgievskie 
Statoil, was taken to the office of her boss for an 'educational conversation' when she was seen wearing a St George ribbon. The company explained that it 'does not encourage the demonstration of political views at the workplace'. ${ }^{132}$

In Latvia, an MP announced plans to introduce a bill in the Saeima which would make it illegal to wear the ribbon in public places; repeat offenders could be given a $€ 700$ fine or fifteen days behind bars. ${ }^{133}$ The fact that this politician had no party affiliation and apparently also no support for his proposal did not prevent the Russian press, including the official government organ, Rossiiskaia gazeta, from writing several stories about it. ${ }^{134} \mathrm{~A}$ more serious attempt was made in Moldova in June 2014 to introduce a ban on the St George ribbon and impose a fine of $\$ 200$ on offenders. ${ }^{135}$

Most of the 'scandals' with St George ribbons in former Soviet republics featured in the Russian media have concerned private, sometimes anonymous individuals and/or marginal groups. The Russian media nevertheless reports on them regularly. In Lithuania, for instance, unidentified persons had glued orange stickers with a kolorady-and-ribbon motive on merchandise produced in Russia, as a warning against buying them. The owners of the supermarket, the Russian media reported, were not planning to do anything about it. ${ }^{136}$

Even so, some Russians continue to go to the 'near abroad' with the ribbon, sometimes clearly in order to provoke reactions. In spring 2015 a group of aggressively pro-Putin Russian bikers, the Night Wolves, celebrated the 7oth anniversary of the Victory by touring neighbouring

lenty' (St George Ribbons Taken Away from Veterans at the Estonian Border), Komsomol'skaia pravda, 11 May $2014<$ http://www.spb.kp.ru/online/news/173200o/>.

132 'Georgievskaia lentochka na grudi sotrudnitsy kompanii Statoil napugala v Estonii politika i biznesmena' (St George Ribbon on the Breast of an Employee of Statoil Company in Estonia Frightened a Politician and Businessman), Komsomol'skaia pravda, 8 May 2015 $<$ http://www.kp.ru/online/news/2050541/>.

${ }^{133}$ Nadezhda Ermolaeva, 'V Latvii predlozhili sazhat' v tiur'mu za noshenie georgievskoi lentochki' (Proposal in Latvia to Throw People in Jail for Wearing St George Ribbons) Rossiiskaia gazeta, 6 May 2015 <http://www.rg.ru/2015/05/o6/latvia-site-anons.html>.

134 Nadezhda Ermolaeva, 'Seim Latvii rassmotrit predlozhenie o zaprete georgievskoi lentochki' (Saima to Discuss Proposal to Ban St George Ribbons), Rossiiskaia gazeta, 13 May $2015<$ http://www.rg.ru/2015/05/13/latvia-site-anons.html>.

135 Svetlana Gamova, 'V Moldavii mogut shtrafovat' za georgievskuiu lentochku' (In Moldova, People May Be Fined for St George Ribbons), Nezavisimaia gazeta, 6 June 2014; 'V Moldove za noshenie Georgievskoi lentochki budut shtrafovat' na 200 dollarov' (In Moldova People May Be Fined \$20o for Wearing St George Ribbons), Komsomol'skaia pravda, 14 July 2014 <http://www.kp.md/daily/26239/312136o/>.

${ }^{136}$ Aleksei Morozov, 'V Litve rossiiskie tovary markiruiut oskorbitel'nym stikerom' (In Lithuania, Russian Goods Marked with an Insulting Sticker), Komsomol'skaia pravda, 6 January $2015<$ http://www.kp.ru/daily/26327.2/3209759/>. 
countries, and got into a squabble in Tbilisi with a senior citizen who tried to tear their ribbons off their chests. When her mobile phone fell to the ground and broke during the tiff, the bikers and not the woman were charged with misconduct, confirming Russian suspicions that Russians always have the burden of proof weighted against them. ${ }^{137}$

Many of the 'incidents' recorded above were so minor that the Russian media, one might think, could well have ignored them without neglecting its journalistic duties as normally understood. Therefore, the fact that it so often chooses to devote space to them is significant in itself. They seem to be part of a master narrative of Russia as a besieged fortress: Russians everywhere abroad - and particularly in the 'near abroad' - are a vulnerable and persecuted minority. This narrative can be interpreted as an element in a nation-building strategy, albeit with definite costs. As noted, identity-building is relational and contrastive. A strong 'we' is premised on the construction of a strongly differentiated 'Other'. In this case, 'the Other' encompasses virtually the entire outside word. A cohesive Russian national unity is bought at the expense of increasing isolation from the international community.

Some Russian firms believe that they may suffer from a harsher international business climate by being associated with the St George ribbon. The leading business newspaper, Kommersant, observed that most of the official sponsors of the St George ribbon campaign are small or medium-sized companies, and speculated that larger firms which were more dependent on export kept away, fearing that association with the campaign could create image problems for them abroad. ${ }^{138}$ Some firms allegedly even hesitated at first to buy ribbons for their employees, but evidently concluded that the potential damage which could be incurred vis-à-vis the Russian authorities by refusing was greater than reduced profits abroad.

In the official Russian media, victory in the Great Fatherland War is always presented as the result of a Herculean effort on the part of all the Soviet nations, not only Russia. However, the Putin era has seen some subtle changes in that regard. The Victory is ever more closely associated with the Russian state and the introduction of the St George ribbon symbolizes that turn. The provenance of this symbol is indisputably Russian, and state leaders in other post-Soviet countries feel that they

137 'Rossiiskikh baikerov zastavili v Tbilisi sniat' georgievskie lenty' (Russian Bikers in Tbilisi were Forced to Take Off Their St George Ribbons), RIA Novosti, 2 May $2015<\mathrm{http}$ :// ria.ru/world/20150502/1062182387.html>.

${ }^{138}$ Surnacheva, 'Lentochnyi konveier'. 
need their own imagery in order to highlight their national contribution to the victory. ${ }^{139}$ Unsurprisingly, Ukraine has taken the lead here. In 2014 Ukraine stopped using the St George ribbon altogether and introduced a red poppy instead. ${ }^{140}$ Despite Ukrainian claims that it is a 'European' symbol, the red poppy is used only in the British Isles, and not on 8 May, but on Remembrance Day, 11 November. Furthermore, its roots go back to the First World War, not the Second. The Ukrainian change of symbols is clearly intended to signal not only a clean break with the Soviet past but also that Ukraine is a 'European country', a point made abundantly clear by switching to 8 May as the day of commemoration.

Not only Ukraine but virtually all post-Soviet countries, including some of Russia's closest allies, have felt increasingly uneasy about the St George ribbon as a common victory symbol. ${ }^{141}$ Kyrgyzstan and Kazakhstan now celebrate victory under their national colours - red and yellow in Kyrgyzstan and light blue in Kazakhstan. ${ }^{142}$ Even more noteworthy was President Aleksandr Lukashenko's solution in Belarus. He evidently felt that he had ended up between the hammer and the anvil: on the one hand, he did not want to antagonize his powerful Russian partner in their common Union-State; on the other hand, his nation-building strategy increasingly focused on Belarusian national themes and symbols. As late as 2013 customers in some Belarusian supermarkets received a St George ribbon for free together with their receipts, ${ }^{143}$ but in the following year this practice was increasingly frowned upon. In 2015 a new national Victory ribbon was introduced: red and green - the colours of the Belarusian flag - with an apple blossom appended. However, Lukashenko himself and his closest entourage during the victory celebrations did not wear 'pure' apple blossom ribbons, but opted for a hybrid version: half of it was orange and

139 Svetlana Gamova, 'Velikaia Pobeda v SNG uzhe ne odna na vsekh. Georgievskaia lenta stala simvolom raskola Sodruzhestva Nezavisimykh Gosudarstv' (In the CIS the Great Victory is No Longer the Same for Everyone: The St George Ribbon has Become a Symbol of Schism in the Community of Independent States), Nezavisimaia gazeta, 27 April $2015<$ http://www.ng.ru/courier/2015-04-27/9_victory.html>.

${ }^{140}$ Anastasiia Novikova, 'Kiev otkazalsia'.

${ }^{141}$ Ihar Karney and Daisy Sindelar, 'For Victory Day, Post-Soviets Show their Colors - Just not Orange and Black', RFE/RL, 7 May $2015<$ http://www.rferl.org/content/victoryday-st-george-ribbon-orange-and-black/26999911.html>.

${ }^{142}$ 'V Kazakhstane nachalas' kampaniia protiv georgievskoi lentochki' (A Campaign has Started in Kazakhstan Against the St George Ribbon), Vzgliad, 11 April $2015<$ http:// vz.ru/news/2015/4/11/739447.html>.

143 “"Stop imperiia”. Belorusskie oppozitsionery prizyvaiut GAI borot'sia s georgievskimi lentochkami' (Stop the Empire: Belarusian Oppositionists Call Upon Traffic Police to Fight Against St George Ribbons), Novaia gazeta, 29 September $2014<$ http://www. novayagazeta.ru/politics/65481.html? $\mathrm{p}=2>$. 
black, while the other half was the new red and green Belarusian ribbon, replete with the apple flower (fig. 20). ${ }^{144}$ This episode graphically illustrated how sensitive the symbol issue has become in Russia's relations with other CIS countries, and how important it is for state leaders in neighbouring countries not to make any false steps.

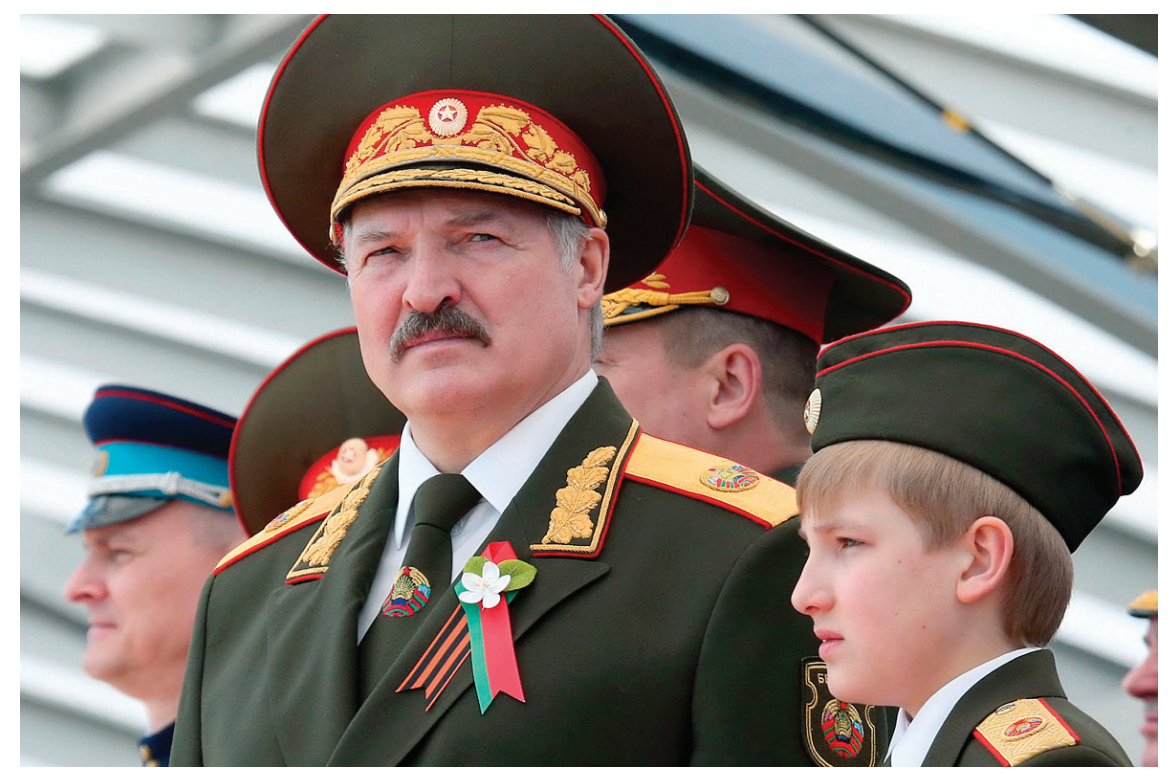

Fig. 20. Lukashenko with his youngest son, Nikolai, Minsk 2015. Galereia S.ART. All rights reserved.

\section{Conclusions}

The ribbon of St George is semantically open and ambiguous, as are all symbols. Our understanding of it is based entirely on our knowledge of how it has been used historically, and our assumptions about the intentions of those who are using it today. The colours of Ksenia Sobchak's bathing suit and the outfit of the Strelkov-Girkin couple were the same, but patriotic Russians reacted very negatively in the first instance and not in the second, since Sobchak is a well-known oppositionist figure and Strelkov has a reputation as a nationalist. And if we are instinctively upset by a picture of an orange-and-black striped swastika, it is because we know

144 Gennadii Mozheiko, 'Aleksandr Lukashenko priletel v Moskvu s georgievskoi lentochkoi na grudi' (Aleksandr Lukashenko Flies to Moscow with a St George Ribbon on His Chest), Komsomol'skaia pravda, 7 May $2015<$ http://www.kompravda.eu/ daily/26378.4/3257216/>. 
how this symbol was used in European history in the twentieth century. That should warn us against trying to interpret symbols on the basis of their design or colours. ${ }^{145}$ Their message, as Anthony Cohen has noted, is entirely 'in the minds of the beholders'.

Some national symbols may be so old and well-established that their origins are difficult to trace, so that they may come to be seen as a 'natural' part of the nation. This is not the case with recently introduced symbols: it is much easier to examine why, how and by whom they were installed. The Russian St George ribbon campaign is one such example.

While the visibility of the St George ribbon in Russian victory celebrations has increased every year since it was introduced in 2005, culminating with the 7oth anniversary in 2015, this symbol became a major emblem of the current Russian regime only in Putin's third term, that is, after 2008. This turn was clearly connected to two events - the massive anti-regime demonstrations in winter 2011/12, and the Ukraine crisis and the Donbas war in 2014 onwards. In the first case, the ribbon was used as a distinguishing mark vis-à-vis the pro-Western opposition; in the second, as a rallying standard in an undeclared war against a neighbouring state. In both cases it has proved its usefulness to the full.

Many Russian oppositionists with good reason regard the St George ribbon as a tool of 'political technology'. ${ }^{146}$ Authoritarian state leaders strenuously try to equate support for the country with loyalty towards the regime, ${ }^{147}$ and it is not difficult to see how this symbol is being manipulated by Russian authorities for both community-building purposes and regime legitimation simultaneously. On the one hand, the ambiguous quality of the ribbon symbol makes it possible to sell it to different ideological groups in Russian society ranging from conservatives, monarchists and Orthodox to Communists and Soviet nostalgics. Presenting it as harkening back to tsarist times and to the Second World War at the same time was clearly intentional and highly successful.

\footnotetext{
${ }^{145}$ Karen A. Cerulo offers an example of an infelicitous attempt to measure the 'visual syntax' of national symbols in 'Symbols and the World System: National Anthems and Flags', Sociological Forum, 8, 1993, 2, pp. 243-71.

${ }^{146}$ See, for example, Latynina, 'Georgievskaia lentochka'.

147 Claes Arvidsson and Lars Erik Blomqvist (eds), Symbols of Power: The Esthetics of Political Legitimation in the Soviet Union and Eastern Europe, Stockholm, 1987; Lane, The Rites of Rulers, ch. 9; Jan Kubik, The Power of Symbols Against the Symbols of Power: The Rise of Solidarity and the Fall of State Socialism in Poland, University Park, PA, 1994; Montserrat Guibernau, Belonging: Solidarity and Division in Modern Societies, Cambridge, 2013.
} 
No doubt, a Russian national victory symbol could have been constructed and framed in a way that it could have appealed also to the third major ideological group in Russian society - the liberals. Instead, we see that in recent years the ribbon symbol has erected an identity boundary between mainstream Russian society and this group. The liberals are so few in number and so firmly set in their anti-Putin ways that it would be hopeless to recruit them as a support group for the regime. But, paradoxically, they may also inadvertently be contributing to Russian nation-building and political consolidation as a contrasting foil for those defined as the in-group. Anti-Putin liberals can be portrayed as carriers of alien, dangerous and un-national ideas threatening to the Russian nation, as Boris Vishnevskii writes in Ekho Moskvy:

From being a sign of military valour [the St George ribbon] has been turned into a symbol of loyalty towards the Putin regime and Putin personally. It has become a symbol of patriotism on display rather than one of genuine patriotism. It is a symbol of a besieged fortress since, as the Kremlin-controlled TV media are trying to assure us, Russia is surrounded by enemies on all sides and all of the besieged people must rally around their leader. Those who fail to do so are traitors, defectors, and fifth columnists. ${ }^{148}$

The ribbon symbol is being used as a potent weapon in a 'cultural war' within the nation, as John Hutchinson describes it. However, it takes two to tango: both the in-group and the out-group contribute to the boundarybased construction of communal identity. Some anti-Putin oppositionists, with their harsh attacks not only on the symbol but also on those who wear it, actively contribute to this boundary-building.

While the St George ribbon in Russian domestic politics functions as a litmus test for regime support, it also marks Russia off from the outside world. When political leaders in neighbouring countries, fearing Russian cultural neo-imperialism, refuse to use a shared but Russian-made victory symbol and introduce their own instead, Russians learn that 'the world out there' is a hostile place and it's time to rally around their leader.

${ }^{148}$ Vishnevskii, 'Ot simvola edinstva'. 